The University of Akron

IdeaExchange@UAkron

Akron Law Review

Akron Law Journals

November 2017

\title{
For the Greater Good: The Subordination of Reproductive Freedom to State Interests in the United States and China
}

Marisa S. Cianciarulo

Please take a moment to share how this work helps you through this survey. Your feedback will be important as we plan further development of our repository.

Follow this and additional works at: http://ideaexchange.uakron.edu/akronlawreview

Part of the Human Rights Law Commons

\section{Recommended Citation}

Cianciarulo, Marisa S. (2017) "For the Greater Good: The Subordination of Reproductive Freedom to State Interests in the United States and China," Akron Law Review: Vol. 51 : Iss. 1 , Article 3.

Available at: http://ideaexchange.uakron.edu/akronlawreview/vol51/iss1/3

This Article is brought to you for free and open access by Akron Law Journals at IdeaExchange@UAkron, the institutional repository of The University of Akron in Akron, Ohio, USA. It has been accepted for inclusion in Akron Law Review by an authorized administrator of IdeaExchange@UAkron. For more information, please contactmjon@uakron.edu, uapress@uakron.edu. 


\title{
For THE GREATER GOOD: THE SUBORDINATION OF REPRODUCTIVE FREEDOM TO STATE INTERESTS IN THE UNITED STATES AND CHINA
}

\author{
Marisa S. Cianciarulo*
}

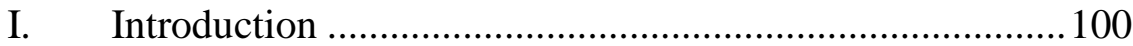

II. International Human Rights Principles................................103

A. On Freedom of Choice.................................................104

B. On Responsibility to Society .......................................108

III. U.S. Abortion Laws: Reproductive Freedom vs.

Prenatal Life ......................................................................111

A. U.S. Abortion Law ......................................................112

1. The Constitutional Framework: Roe v. Wade and Its Progeny ......................................................112

2. State Laws Regulating Abortion..............................114

B. Rationale Supporting Restrictions on Access to

Abortion: Life Begins at Conception............................116

C. Beyond the Rationale: Religion- and Conscience-

Based Restrictions on Access to Contraception and

Sex Education Impede Protection of Prenatal Life.....120

IV. China's Population Control Law and Policies:

Reproductive Freedom vs. Sustainability.....

A. China's Population Control Law and Policies .............123

B. Rationale Supporting Coercive Population Control:

Excessive Population Growth Impedes

Development and Threatens Sustainability

C. Beyond the Rationale: China's Coercive Population

\footnotetext{
* Professor of Law, Associate Dean for Academic Affairs, Chapman University Fowler School of Law. The author wishes to thank Ellena Nguyen and Grace Nguyen for their outstanding research assistance; Sherry Leysen and her colleagues in the Hugh and Hazel Darling Law Library for their outstanding research assistance; Dean Matt Parlow, Associate Dean for Research and Faculty Development Donald Kochan, and Chapman University for providing generous support for the writing of this Article; and Maria T. Ciccolini, Calleigh Olson, and the staff of the Akron Law Review for their excellent editing.
} 
Control Program Has Far Exceeded its Goals, Creating a Demographic Crisis and Inflicting

Needless Brutality.

1. Human Rights Violations: Forced Abortions, Stigmatized Children, and Disposal of Female

Children

2. Demographic Crises: A Shortage of Young People and a Shortage of Females...

V. Whether State Interests Should Ever Supersede an

Individual's Right to Reproductive Freedom

A. Compulsory Sex Education Achieves the Goals of Abortion Prevention and Population Control in the Least Coercive Manner and Within the Bounds of Human Rights Norms.

B. Financial Incentives and Penalties Prevent Excessive Population Growth Without the Use of Physical Force but may Nevertheless Violate Human Rights Norms.

C. Forced Abortion, Forced Sterilization, and Forced Child-Bearing are Inconsistent with Human Rights Principles.

VI

Conclusion

\section{INTRODUCTION}

One of the most contentious debates in the United States and internationally concerns the extent of a woman's right to control her reproductive capacity. The debate arises from the tension between the right of the individual to reproductive freedom and the right of the society in which that individual lives to restrict reproductive freedom in service to a greater good. While most people agree that individuals have some right to reproductive freedom and that society has some right to impose limitations on that freedom, there exists a vast and hostile territory of disagreement as to where one right ends and the other begins. ${ }^{1}$ Juxtaposing recently proposed and enacted abortion restrictions

1. See Luke T. Lee, Population: The Human Rights Approach, 6 Colo. J. INT’L ENVTL. L. \& POL’Y 327, 339-40 (1995):

[M]odern medicine's ability to significantly reduce mortality rates, coupled with the reality of the Earth's finite resources being exploited by an ever-burgeoning population, led inexorably to the reversal of the pronatalist policy. The now-pressing need for a 
in the United States with the recently amended coercive population control policy of China as the framework for discussion, this Article attempts to navigate this territory using international human rights law as its guide. The ultimate goal is to determine whether state-coerced pregnancy, state-coerced abortion, and other forms of reproductive coercion are ever permissible and, if so, under what circumstances.

The United States has a patchwork of state laws restricting abortion (and thus coercing pregnancy) that purport to advance those states' interests in protecting prenatal life at the expense of individual reproductive freedom. ${ }^{2}$ In contrast, China has long had a coercive population control policy that it has enforced through forced abortions and forced sterilizations. ${ }^{3}$ These are not the only countries that restrict abortion or use coercive methods for population control to advance state causes, but this Article focuses on these two countries for several reasons. First, the United States has a long, well-documented jurisprudential and legislative history of debating whether a woman should have the right to terminate a pregnancy and under what conditions. ${ }^{4}$ These debates, as well as the variety of state laws restricting abortion that have come about in the years since the landmark 1973 Supreme Court decision in Roe v. Wade, ${ }^{5}$ provide extensive insight into the religious, societal, and theoretical bases of the anti-abortion movement. Second, China arguably has the most notorious population

quick transition from centuries-old pronatalism to antinatalism is bound to produce uneven results, and the task of reconciling the individual and collective rights requires nothing short of Solomonic wisdom.

2. See infra Part III.A.2.

3. See infra Part IV.A.

4. See, e.g., Roe v. Wade, 410 U.S. 113 (1973) (holding that women have a constitutionally protected right to abortion under the Fourteenth Amendment Due Process Clause and establishing a three-tiered system, based on the three trimesters of pregnancy, for determining the extent of the right); Webster v. Reproductive Health Services, 492 U.S. 490 (1989) (upholding a state ban on the use of state employees and facilities for abortions); Planned Parenthood of Cent. Mo. v. Danforth, 428 U.S. 52 (1976) (overturning a state law requiring a married woman to obtain her husband's consent prior to having an abortion); Harris v. McRae, 448 U.S. 297 (1980) (upholding a federal ban on Medicaid funding for abortions except in cases of rape, incest, or danger to the life of the mother); Hodgson v. Minnesota, 497 U.S. 417 (1990) (overturning a state law that required minors to obtain the consent of both parents prior to having an abortion); Planned Parenthood of Se. Pa. v. Casey, 505 U.S. 833 (1992) (reversing the holding in Roe v. Wade that prohibited state involvement in first-trimester abortions, paving the way for state laws requiring waiting periods and pre-abortion counseling); Stenberg v. Carhart, 520 U.S. 914 (2000) (invalidating a state ban on partial birth abortions); Gonzales v. Carhart, 550 U.S. 124 (2007) (upholding a federal ban on partial birth abortions); Whole Woman's Health v. Hellerstedt, 136 S.Ct. 2292 (2016) (striking down a state law requiring physicians who perform abortions to have admitting privileges at a local hospital and requiring clinics to install hospital-grade facilities).

5. 410 U.S. 113 (1973). 
control policy in the world, known as the one-child policy until January 2016 and the two-child policy since then. ${ }^{6}$ China has continued to aggressively enforce population control since 1979, even in the face of significant international and domestic opposition. China and the United States thus enforce laws and policies that effect opposing forms of restrictions on reproductive freedom: coerced pregnancy and coerced abortion.

Despite the apparent diametric opposition of China's coercive population control law and policies on the one hand and U.S. antiabortion laws on the other, there are fascinating similarities between them. First, carried to their extremes, both forms of restriction involve the gravest manifestation of the tension between individual reproductive rights and a significant human right of another entity (the collective's right to sustainability in the context of China and the right to life of the unborn in the context of the United States). Second, morality and duty to society figure heavily in defenses of both forms of restriction. Finally, both forms of restriction subordinate the reproductive choices of primarily women to the goals of the state. ${ }^{7}$

This Article uses the lens of international human rights law to evaluate the concept of subordinating individual reproductive choice to a perception of the common good. Part II provides an overview of the major international instruments addressing individual rights and how they interact with the rights and responsibilities of the state. Part III discusses anti-abortion laws in the United States and the anti-abortion movement's rationale that protecting prenatal life justifies limiting reproductive choice. Part IV discusses China's vast population control system and the government's rationale that providing a controlled, sustainable population justifies limiting reproductive choice. Part V examines three levels of coercion-compulsory sex education and unrestricted access to contraception, monetary incentive and disincentive programs, and forced abortion and forced child-bearing - and analyzes whether they are consistent with international human rights principles. Finally, the Article concludes that in light of modern access to education and contraception, and the ability to reduce the incidence of unwanted pregnancies via those means, more coercive means are unnecessary (in

6. See infra Part IV.A.

7. See Amy Hampton, Population Control in China: Sacrificing Human Rights for the Greater Good? Birth Control Surgeries: 1971-1986, 11 TULSA J. COMP. \& INT’L L. 321, 357 (2003) (" $[\mathrm{B}]$ irth control programs stem from the needs of the state, not the needs of the women affected ... [W]omen are "treated not as subjects but as objects, tools to be managed and used in the achievement of state plans and goals.'”) (citations omitted). 
the case of monetary incentives and disincentives) and unjustifiable (in the case of forced abortion and forced child-bearing).

\section{INTERNATIONAL HUMAN RIGHTS PRINCIPLES}

The concept of reproductive choice as a human right is a relatively recent one. As one author explained, "[t]he concept of family planning as a human right is of only recent promulgation due to the fact that the requisite knowledge and means to control reproduction must first be accessible," something that did not occur until the latter half of the 20th century. ${ }^{8}$ Relatedly, reproductive freedom as a means of or even a prerequisite to securing human rights, ${ }^{9}$ particularly for women, was a nearly unheard of concept until the latter half of the 20th century. ${ }^{10}$ While numerous international documents proclaimed the equality of women and men between 1945 and 1966, ${ }^{11}$ it was not until the 1968 International Conference on Human Rights that a specific provision on family planning appeared in an international document: "[p]arents have a basic human right to determine freely and responsibly the number and spacing of their children and a right to adequate education and information in this respect.” ${ }^{12}$ The various post-1966 documents, while

8. Diana Babor, Population Growth and Reproductive Rights in International Human Rights Law, 14 CONN. J. INT’L. L. 83, 98 (1999).

9. See Reed Boland, Sudhakar Rao, \& George Zeidenstein, Honoring Human Rights in Population Policies: From Declaration to Action, in PopUlation Policies ReCOnSIDERED: HEAlth, EMPOWERment, AND Rights 89, 91 (Sen, Germain, Chen eds., 1994) (“[E]conomic and political rights, important as they are, have little meaning for women without the freedom to control their reproductive capacity.”).

10. See Babor, supra note 8, at 93 ("The idea that rapid population growth could not be addressed without the greater involvement of women, by providing them with the knowledge and means to control their own fertility and overall reproductive health, was considered an evolutionary breakthrough in what had been a twenty-year search for feasible solutions.”).

11. See, e.g., U.N. Charter art. 1, I 3 ("[H]uman rights and fundamental freedom for all without distinction as to race, sex, language or religion.”); G.A. Res. 217 (III) A, Universal Declaration of Human Rights art. 1 (Dec. 10, 1948) (“All human beings are born free and equal in dignity and rights.”); International Covenant on Civil and Political Rights, U.N. GAOR, 21st Sess., Supp. No. 16, at 52, U.N. Doc. A/6316 (1966) ("All persons are equal before the law and are entitled without any discrimination to the equal protection of the law."); International Covenant on Economic, Social and Cultural Rights, U.N GAOR, 21st Sess., Supp. No. 16, U.N. Doc. A/6316, art. 11(1) and 12(1) (1966) [hereinafter ICESCR] (“[T]he right of everyone to an adequate standard of living for himself and his family, including adequate food, clothing and housing, and to the continuous improvement of living conditions. [T] he right of everyone to the enjoyment of the highest attainable standard of physical and mental health.”).

12. Human Rights Aspects of Family Planning, Final Act of the International Conference on Human Rights at Teheran, Res. XVIII, U.N. Doc. A/CONF. 32/41 at 16 (1968); See also, G.A. Res. 2542, Declaration on Social Progress and Development, Part III, art. 22(b) (Dec. 11, 1969) ("[T]he achievement of the objectives of social progress and development requires the mobilization of the 
advocating individual reproductive freedom, also contain clauses that seem to limit individual choice. These documents require states to respect individual reproductive freedom while also acknowledging limits on that freedom and proclaiming respect for sovereign nations.

\section{A. On Freedom of Choice}

Various United Nations declarations, conventions, programs, and plans specifically encourage or mandate signatories to allow women and men to choose whether and when to have children and how many children to have, as well as to provide women and men with access to family planning information and education. The 1969 U.N. Declaration on Social Progress and Development ${ }^{13}$ listed as essential to those goals the "education, training of personnel, and the provision to families of the knowledge and means necessary to enable them to exercise their right to determine freely and responsibly the number and spacing of their children." 14 The 1974 World Population Plan of Action states that "[a]ll couples and individuals have the basic right to decide freely and responsibly the number and spacing of their children and to have the information, education and means to do so." ${ }^{15}$ The World Population Plan of Action also calls for a reduction in "illegal abortions," 16 implying not only that individuals should have information about and access to family planning, but that in the event of an unwanted

\footnotetext{
necessary resources by national and international action, with particular attention to such means and methods as ... education, training of personnel, and the provision to families of the knowledge and means necessary to enable them to exercise their right to determine freely and responsibly the number and spacing of their children.”); World Population Conference, World Population Plan of Action, U.N. Doc. E/CONF. 60/19, art. 14(f) (1974) ("All couples and individuals have the basic right to decide freely and responsibly the number and spacing of their children and to have the information, education and means to do so; the responsibility of couples and individuals in the exercise of this right takes into account the needs of their living and future children, and their responsibilities towards the community.”); World Conference of the International Women's Year, Declaration of Mexico on the Equality of Women and Their Contribution to Development and Peace, U.N. Doc. E/CONF. 66/34, art. 11 (1975) [hereinafter Mexico Decl.] ("The human body, whether that of woman or man, is inviolable and respect for it is a fundamental element of human dignity and freedom”); Mexico Decl. at art. 12 ("Every couple and every individual has the right to decide freely and responsibly whether or not to have children”); G.A. Res. 34/180, annex, Convention on the Elimination of All Forms of Discrimination against Women, art. 10(h) and 12(1) (Dec. 18, 1979) [hereinafter CEDAW] ("[A]ccess to... information and advice on family planning . . . and access to health care services ... related to family planning.”).

13. G.A. Res. 2542, Declaration on Social Progress and Development (Dec. 11, 1969).

14. Id. at art. 22(b).

15. World Population Conference, World Population Plan of Action, U.N. Doc. E/CONF. 60/19, art. 14(f) (1974).

16. Id. at art. 24(b).
} 
pregnancy, abortion should be available. The Declaration of Mexico on the Equality of Women and Their Contribution to Development and Peace reiterates individuals' right to family planning information, education, and services ${ }^{17}$ and also includes a statement that " $[t]$ he human body, whether that of woman or man, is inviolable and respect for it is a fundamental element of human dignity and freedom." ${ }^{18}$ The 1979 Convention on the Elimination of All Forms of Discrimination against Women (CEDAW) ${ }^{19}$ requires access to family planning education ${ }^{20}$ and access to family planning counseling and services at health care facilities. $^{21}$

In addition to these documents-which, with the exception of the Declaration of Mexico, tend to avoid specific mentions of abortionnumerous subsequent U.N. reports and findings specifically advocate legalization of and access to abortion. For example, a 2011 U.N. report of the Special Rapporteur (independent expert) on the right of everyone to the enjoyment of the highest attainable standard of physical and mental health found that "[c]reation or maintenance of criminal laws with respect to abortion may amount to violations of the obligations of States to respect, protect and fulfil the right to health." ${ }^{22}$ The report echoed earlier documents" assertion that “[d]ignity requires that individuals are free to make personal decisions without interference from the State, especially in an area as important and intimate as sexual and reproductive health." ${ }^{23}$ Similarly, the U.N. Committee for the Elimination of Discrimination against Women consistently emphasizes the importance of access to safe, legal abortions as part of comprehensive women's health care. $^{24}$ The U.N. Committee against

17. Mexican Decl., supra note 12, at art. 12.

18. Id. at art. 11 .

19. CEDAW, supra note 12.

20. Id. at art. 10(h).

21. Id. at arts. 12(1) and 14(2)(a).

22. Anand Grover (Special Rapporteur of Human Rights Council), Interim report of the Special Rapporteur on the right of everyone to the enjoyment of the highest attainable standard of physical and mental health, U.N. Doc. A/66/254, art. 21 (Aug. 3, 2011).

23. Id. at art. 15.

24. See, e.g., U.N., Fourth periodic report of the Gov't of Chile on the measures adopted to implement the provisions of the CEDAW, CEDAW/C/CHI/4, I 282 (May 17, 2004) (expressing concern that Chile does not permit abortion under any circumstances); see generally, CEDAW, supra note 12 (expressing deep concern over the link between highly restrictive abortion laws and increased maternal mortality due to illegal, unsafe abortions, and strongly recommending access to safe, legal abortions). 
Torture found that the failure to provide access to legal abortion amounts to cruel and inhuman treatment. ${ }^{25}$

Others, while not specifically advocating abortion rights, interpret international law as guaranteeing the right to control one's reproductive capacity. For example, the Declaration on Economic, Social, and Cultural Rights requires signatories to provide "for the reduction of the stillbirth rate and of infant mortality and for the healthy development of the child." 26 The U.N. Committee on Economic, Social, and Cultural Rights interpreted this to include "measures to improve child and maternal health, sexual and reproductive health services, including access to family planning, pre- and post-natal care.” ${ }^{27}$

International tribunals have also concluded that international law protects an individual's right to control her reproductive capacity, including a woman's choice whether to terminate a pregnancy. In Paton v. United Kingdom, ${ }^{28}$ the European Court of Human Rights found that the "right to life" acknowledged in the European Convention for the Protection of Human Rights and Fundamental Freedoms ${ }^{29}$ does not extend to fetuses. Therefore, laws permitting abortion are not in violation of the Convention. ${ }^{30}$ Similarly, in R.H. v. Norway ${ }^{31}$ and Boso v. Italy, ${ }^{32}$ the European Commission on Human Rights found that the European Convention's acknowledgment of the "right to life" refers to persons already born and does not grant a father the right to legally challenge a mother's decision to terminate a pregnancy. ${ }^{33}$ In a 1981 case

25. U.N. Comm. Against Torture, Conclusions and recommendations of the Committee against Torture: Peru, 9 23, CAT/C/PER/CO/4 (July 25, 2006).

26. ICESCR, supra note 11, at art. 12.2(a).

27. Comm. on Economic, Social and Cultural Rights, adopted at the Twenty-second Session, CESCR General Comment No. 14: The Right to the Highest Attainable Standard of Health (Art. 12), Contained in Document E/C.12/2000/4, art. 12.2, \ 14 (Aug. 11, 2000).

28. Paton v. United Kingdom, App. No. 8416/78, 3 Eur. H.R. Rep. 408 (1980).

29. Convention for the Protection of Human Rights and Fundamental Freedoms, Sept. 3, 1953, 213 U.N.T.S. 221 [hereinafter ECHR].

30. Paton v. United Kingdom, 3 Eur. H.R. Rep. at 917 (the applicant in the case challenged the right to abortion under Article 2 ("[e]veryone's right to life shall be protected by law" and Article 8 "the right to respect for home and family life") of the ECHR).

31. R.H. v. Norway, Decision on Admissibility, App. No.17004/90, 73 Eur. Comm'n H.R. Dec. \& Rep. 155 (1992). The applicant challenged the right to abortion under Article 2 (“[e]veryone's right to life shall be protected by law”), Article 3 (prohibition of torture), Article 8 (the right to respect for home and family life), and Article 9 (freedom of religion) of the ECHR.

32. Boso v. Italy, App. No.50490/99, Eur. Ct. H.R. 846 (2002). The applicant challenged the right to abortion under Article 2 (“[e]veryone’s right to life shall be protected by law"), Article 8 (the right to respect for home and family life), and Article 12 (the right to found a family) of the ECHR.

33. R.H. v. Norway, 73 Eur. Comm'n H.R. Dec. \& Rep. at 155; Boso v. Italy, Eur. Ct. H.R. at 846. 
brought by U.S. citizens challenging Roe v. Wade, the Inter-American Commission on Human Rights found that the American Declaration of the Rights and Duties of Man $^{34}$ does not guarantee the right to life of the unborn. $^{35}$ In all of these cases, the tribunals have noted that the challenged laws did not provide for unfettered access to abortion, but rather imposed some restrictions on eligibility. ${ }^{36}$

Reproductive freedom, whether implicitly or explicitly acknowledged, is a ubiquitous issue in global and regional international human rights laws and agreements, and is widely accepted as including the right, safely and without state interference, to terminate a pregnancy or to carry a pregnancy to term. ${ }^{37}$ Reproductive freedom is, however, only one component of international human rights law and agreements. Also prevalent, perhaps even more so than the right to reproduce or not,

34. American Declaration of the Rights and Duties of Man, Inter-Am. Comm'n H.R., O.A.S. Res. XXX (1948), reprinted in Basic Documents Pertaining to Human Rights in the Inter-American System, OEA/Ser.L./V./ II.82, doc. 6 rev. 1 at 17 (1992).

35. Baby Boy, Case 2141, Inter-Am. Comm'n H.R. 25, OEA/Ser.L./V/II.54, doc. 9 rev. 1 (1981). The petitioners challenged the U.S. Supreme Court decision in Roe v. Wade, 410 U.S. 113 (1973), under the American Declaration of the Rights and Duties of Man, Article I ("[e]very human being has the right to life..."), Article II ("[a]ll persons are equal before the law ... without distinction as to race, sex, language, creed, or any other factor,"), Article VII ("All children have the right to special protection, care, and aid"), and Article XI ("Every person has the right to the preservation of his health ...”), American Declaration of the Rights and Duties of Man, supra note 34.

36. In Paton v. United Kingdom, App. No. 8416/78, 3 Eur. H.R. Rep. 408 (1980), the Abortion Act only permitted abortion if two registered medical practitioners found that "continuance of the pregnancy would involve risk to the life of the pregnant woman, or of injury to the physical or mental health of the pregnant woman or any existing children of her family, greater than if the pregnancy were terminated" or "that there is a substantial risk that if the child were born it would suffer from such physical or mental abnormalities as to be seriously handicapped." In R.H. v. Norway, Eur. Comm'n H.R. Dec. \& Rep. at 155, Boso v. Italy, Eur. Ct. H.R. at 846, and Baby Boy, Inter-Am. Comm'n H.R. at 25, the laws in question each placed increased restrictions on access to abortion as the pregnancy progressed.

37. See, e.g., Babor, supra note 8, at 112-13 ("Based on the prevalence of domestic laws which reflect the right to an induced abortion, 'it is clear that the general principles of law common to civilized nations, as well as the actual state practice of states, establish reproductive freedom as an international human right'”) (quoting Berta E. Hernandez, To Bear or Not to Bear: Reproductive Freedom as an International Human Right, 17 BROOK. J. INT'L L. 309, 309 n.1 (1991)); see also id. at 357:

[T]he enactment of laws limiting family planning has been based solely upon the state's needs - the desire to defer to influential religious groups or to curb or enhance population. Such a “'sovereign"” agenda without regard for and in derogation of the individual's human rights was precisely the type of government activity condemned at Nuremburg. The use of an individual as a pawn of the state without regard or respect for the individual's rights pertaining to family life is contrary to human rights principles. Dictating reproduction to further governmental, often linked with religious, goals impermissibly erodes the very harmony, respect and dignity to which human beings are entitled and that modern day international human rights laws were designed to protect. 
is the right of existing members of society to a world with sufficient resources and a healthy environment. While distinct from the perceived responsibility to protect the unborn, this right also pits the rights of the individual to create potential human life against the rights of existing human beings.

\section{B. On Responsibility to Society}

While it is clear that international law embodies a right to reproductive freedom, the extent of that right is not nearly as defined. The right coexists with other rights, the fulfillment of which necessitates some limit on reproductive freedom. Human beings in general have a right to a world with resources sufficient to provide the opportunity to attain an adequate standard of living. While the world may not currently be on a crash course to "massive misery and hunger," (at least through overpopulation), overpopulation is certainly a contributing factor-if not the primary cause of-misery and hunger in poverty-stricken, highfertility parts of the world. ${ }^{38}$ Moreover, each family's existing children have the same right to resources, as well as additional rights, discussed more fully below. ${ }^{39}$ To the extent that unfettered procreation raises concerns for the environment, government resources, and sustainability, the right to reproductive freedom potentially conflicts with these other rights.

International human rights documents reflect this need to balance the rights of individuals to procreate with the rights of existing human beings. The Universal Declaration of Human Rights acknowledges that each individual is entitled to "a standard of living adequate for the health and well-being of himself and of his family, including food, clothing,

38. See Amartya Sen, Fertility and Coercion, 63 U. CHI. L. REV. 1035, 1039-40 (1996) ("Despite the importance of reproductive rights, if their exercise were to generate disasters such as massive misery and hunger, then we would have to question whether they deserve full protection."). See also, Wolfgang Lutz \& Sergei Scherbov, Exploratory Extension of IIASA's World Population Projections: Scenarios to 2300, Interim Report, International Institute of Applied Systems Analysis, at 21 (2008), http://pure.iiasa.ac.at/8761/1/IR-08-022.pdf [https://perma.cc/HH5T-MYRF]. (acknowledging Africa's "destructive speed of population growth" and its connection with poverty and human suffering); U.N. Dep’t of Economic and Social Affairs, Population Division, Seven Billion and Growing: The Role of Population Policy in Achieving Sustainability, No. 2011/3 (2011) at 19 (reporting that "[h]igh fertility is associated with the persistence of poverty within countries because low-income groups generally have higher fertility than high-income groups"). Experts also tend to agree that a declining global population "will result in a better and more sustainable development around the world.” Lutz \& Scherbov, supra note 38.

39. See infra notes $43-52$ and accompanying text. 
housing, and medical care, and necessary social services." 40 This right also appears in the International Covenant on Economic, Social, and Cultural Rights. ${ }^{41}$ A number of other international human rights documents, while not specifically acknowledging the right to an adequate standard of living, acknowledge related rights that also cannot be realized if the earth were to reach the point of "massive misery and hunger" due to overpopulation. ${ }^{42}$

The Convention on the Rights of the Child (CRC) ${ }^{43}$ also acknowledges a number of rights, the realization of which depends on sustainability and responsible procreation. Echoing the Universal Declaration of Human Rights and the International Covenant on Economic, Social, and Cultural Rights, the CRC asserts that every child is entitled to: a "standard of living adequate for the child's physical, mental, spiritual, moral, and social development" ${ }^{44}$ and "the highest attainable standard of health;" 45 freedom from violence, abuse, and neglect; ${ }^{46}$ and protection against exploitation. ${ }^{47}$ The CRC places a great deal of responsibility on states to secure these rights for children by providing every child with costly services, ${ }^{48}$ such as: free primary education and access to higher education; ${ }^{49}$ well-staffed safety and health services; ${ }^{50}$ special needs assistance and services; ${ }^{51}$ and "material assistance and support programmes, particularly with regard to nutrition, clothing, and housing." 52

In an effort to balance these individual rights and state responsibilities with the right to reproductive freedom, international human rights documents addressing reproductive freedom have emphasized responsible procreation. The Declaration on Social Progress

40. G.A. Res. 217 (III) A, Universal Declaration of Human Rights art. 25(1) (Dec. 10, 1948).

41. ICESCR, supra note 11, at art. 11.

42. Sen, supra note 38.

43. G.A. Res. 44/25, 44 U.N. GAOR Supp. No. 49, Convention on the Rights of the Child, U.N. Doc. A/44/736 (Nov. 20, 1989) [hereinafter CRC].

44. Id. at art. 27(1).

45. Id. at art. 24(1).

46. Id. at art. 19(1).

47. Id. at arts. 32-36.

48. See Seven Billion and Growing, supra note 38, at 20 ("Declining numbers of children would have opened numerous opportunities to improve the health and educational prospects of future generations. The majority of the least developed countries are currently facing challenges in providing such opportunities because of delays in reducing fertility.”).

49. CRC, supra note 43, at art. 28.

50. Id. at art. 3(3).

51. Id. at art. 23(3).

52. Id. at art. 27(3). 
and Development, the International Conference on Human Rights at Teheran, and CEDAW speak of women's and men's right to decide "freely and responsibly" on the number and spacing of their children. ${ }^{53}$ The World Population Plan of Action was more explicit about what prospective parents should take into account when deciding freely: "the needs of their living and future children, and their responsibilities towards the community." ${ }^{4}$ Similarly, the heads of state who signed the 1966 Declaration on Population stated their belief that "family planning, by assuring greater opportunity to each person, frees man to attain his individual dignity and reach his full potential.”55

The rights and responsibilities of the state are also essential to the discussion of reproductive freedom. As discussed above, the CRC places a great deal of responsibility on governments to provide necessary services to children, ${ }^{56}$ including an education conducive to the "development of the child's personality, talents, and mental and physical

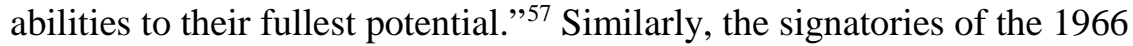
Declaration on Population urged recognition of "the population problem ... as a principal element in long-range national planning if governments are to achieve their economic goals and fulfill the aspirations of their people." 58 The World Population Plan of Action provides that "the formulation and implementation of population policies is the sovereign right of each nation" and "is to be exercised in accordance with national objectives and needs and without external interference." ${ }^{59}$ As one group of authors observed, the rights and responsibilities accorded to governments diminishes the role of individual reproductive rights, thus "making individual human rights subordinate to national objectives and values . . ." ${ }^{60}$ These authors raise

53. Declaration on Social Progress and Development, supra note 12, at art. 4 (emphasis added); International Conference on Human Rights at Teheran, supra note 12, at art. II (16); CEDAW, supra note 12, at art. 16(1)(e).

54. World Population Plan of Action, supra note 12, at art. 14(f).

55. U.N. Population Newsletter, Declaration on Population by World Leaders, Population Division, at 44 (Apr. 1968).

56. See CRC, supra note 43, at art. 4 (“[P]arties shall undertake all appropriate legislative, administrative, and other measures for the implementation of the rights recognized in the present Convention... [and] undertake such measures to the maximum extent of their available resources.”).

57. Id. at art. 29(1)(a).

58. Declaration on Population by World Leaders, supra note 55.

59. World Population Plan of Action, supra note 12, at art. 14.

60. Boland et al., supra note 9, at 93 . 
a difficult and related question: "Who is to decide whether persons are acting responsibly?”61

Despite the tension between the rights of the individual and the rights of society or the government - the same tension present in the debate over the proper extent of reproductive freedom-the basic proposition that reproductive freedom is a human right is undisputed. ${ }^{62}$ As the preceding discussion presages, the debate lies elsewhere: where the rights of the individual end and the rights of the government or society begin. The following two Parts address how the various U.S. states and the Chinese government have answered that question.

\section{U.S. ABORTION LAWS: REPRODUCTIVE FREEDOM VS. PRENATAL LIFE}

The debate over reproductive freedom in the United States has raged over several decades, beginning with married couples' right to use contraception and progressing to a woman's right to have an abortion. Questions of morality, often (but not always) religion-based, have permeated the debates. While the question of consenting adults' right to use contraception has largely been resolved, the abortion debate continues to rage, resembling not so much a debate as a culture war. Those who are pro-choice believe the right to an abortion encompasses the right to decide for oneself when life begins and the right to make decisions regarding one's own body. Those who are anti-choice believe incontrovertibly that life begins at conception, that the fetal stages are no different from any other stages of human development, and that it is as much the duty of society to protect fetal life as it is to protect any other vulnerable human being, such as children or the disabled. This section will explore the anti-abortion movement, how the U.S. legal system has struggled to find a balance between the duty to protect prenatal life and the duty to protect reproductive freedom, and the practical effect of restrictions on the right to abortions.

61. Id.

62. See Babor, supra note 8, at 105-06 (1999) ("In view of the numerous United Nations documents that uphold family planning as a human right, in addition to the general practice of many states today that provide the knowledge and means of reproductive control to their citizens ... the human right of family planning is recognized as a principle of customary international law.”). See also, Bharati Sadasivam, The Rights Framework in Reproductive Health Advocacy - A Reappraisal, 8 HASTINGS WOMEN's L.J. 313, 323 (1997) (asserting that the declarations and statements regarding reproductive freedom "constitute a vast body of 'soft law' which, although lacking the binding nature of treaty law, has undeniable value in advancing reproductive health goals”). 


\section{A. U.S. Abortion Law}

1. The Constitutional Framework: Roe v. Wade and Its Progeny

In the culmination of several challenges to state laws restricting abortion, the U.S. Supreme Court held in Roe v. Wade that the Due Process Clause of the Fourteenth Amendment ${ }^{63}$ guarantees a woman a limited right to abortion. ${ }^{64}$ The Court balanced this right with the responsibility of the state, but that responsibility was to the patient rather than to the state's interests in protecting prenatal life: "The State has a legitimate interest in seeing to it that abortion, like any other medical procedure, is performed under circumstances that ensure maximum safety for the patient." 65 The Court provided guidelines for state regulation: i) within the first trimester, the state's interest in protecting prenatal life is minimal and thus a woman is entitled to an abortion with very little state interference; ii) within the second trimester, the state's interest in protecting prenatal life is heightened, and thus the state may impose some restrictions on abortion; and iii) within the third trimester, during which a fetus typically becomes viable, the state may impose even more restrictions on abortion. ${ }^{66}$

Three years after Roe, the Supreme Court applied the Roe formula to a 1974 Missouri law that placed restrictions on abortion. The law required, among other things, written consent from the spouse of a woman seeking an abortion during the first 12 weeks of pregnancy, unless the abortion would save the mother's life; ${ }^{67}$ parental consent if the woman was younger than 18, irrespective of the trimester in which the abortion was sought; ${ }^{68}$ and physicians to exercise professional care in preserving a fetus's life or risk being charged with manslaughter. ${ }^{69}$ The lawsuit challenging the statute, Planned Parenthood of Central Missouri $v$. Danforth, ${ }^{70}$ came before the Supreme Court in 1976. Relying on the Roe framework, the Court held that the spousal consent and parental consent provisions were unconstitutional because the state cannot delegate the authority to prevent an abortion to anyone but the physician

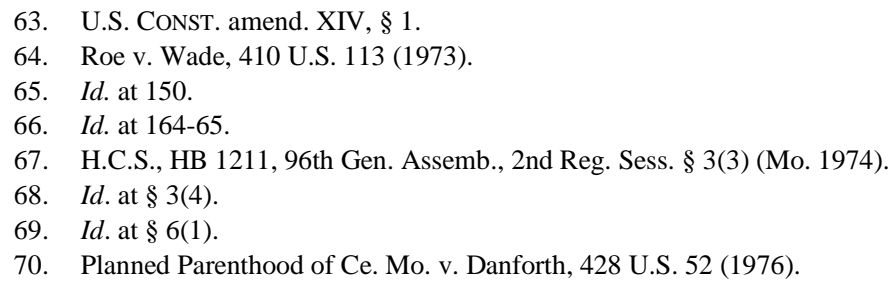


and the woman during the first trimester of pregnancy. ${ }^{71}$ The Court also held that the manslaughter provision was unconstitutional because it required physicians to preserve the life of the fetus at any stage of pregnancy, including within the first trimester. ${ }^{72}$

The Court again rejected a spousal consent requirement in 1992 when it decided Planned Parenthood of Southeastern Pennsylvania $v$. Casey. ${ }^{73}$ For the first time since Roe v. Wade, however, the Court upheld first-trimester regulation of abortion. In doing so, the Court reaffirmed Roe's central holding that "viability marks the earliest point at which the State's interest in fetal life is constitutionally adequate to justify a legislative ban on nontherapeutic abortions." ${ }^{74}$ The Court rejected, however, Roe's strict trimester framework and replaced it with an "undue burden” test: "a state regulation [that] has the purpose or effect of placing a substantial obstacle in the path of a woman seeking an abortion of a nonviable fetus . . is invalid." 75 Thus, even first-trimester regulations were permissible, as long as they did not impose an undue burden. The Court rejected arguments that a 24-hour waiting period and its concomitant delays and increased costs presented an undue burden. ${ }^{76}$ Similarly, the Court found that a parental consent requirement did not present an undue burden because there was a judicial bypass provision and the consent of only one parent or guardian was required. ${ }^{77}$ Upholding its decision and reasoning in Danforth, the Court found Pennsylvania's spousal notification provision to be unconstitutional. ${ }^{78}$

Roe and its progeny have proven to be a lightning rod for debate between advocates for the freedom of choice and advocates for the protection of prenatal life. The decades following Roe have seen various attempts by states to restrict abortion access as much as possible while not technically violating the Fourteenth Amendment. States have also tried to pass laws clearly not supported by Roe in an attempt to litigate and ultimately overturn it. The Court has consistently struck down laws that, albeit furthering a valid state interest, have "the effect of placing a substantial obstacle in the path of a woman's choice"79 and thereby

Id. at $69,74-75$.

72. Id. at 83.

73. Planned Parenthood of Se. Pa. v. Casey, 505 U.S. 833 (1992).

74. Id. at 860 .

75. Id. at 877.

76. Id. at 887.

77. Id. at 899 .

78. Id. at 897-98.

79. Id. at 877 . 
"impos[ing] an undue burden on the right" to an abortion. ${ }^{80}$ The debate nevertheless continues to rage, with states continuing to propose and pass restrictions that clearly trespass beyond the boundaries set by Roe and its progeny. ${ }^{81}$

\section{State Laws Regulating Abortion}

The United States has a patchwork of state laws regulating abortion. Ever since the U.S. Supreme Court in Planned Parenthood v. Casey gave states the right to regulate first-trimester abortions, states have imposed first-trimester restrictions such as mandatory counseling and waiting periods. ${ }^{82}$ Other restrictions include parental consent or notification requirements, ${ }^{83}$ mandatory ultrasounds with audio and an

80. Id. at 878 .

81. See, e.g., N.D. ALS 119, HB 1456 (2013) (enacted) (outlawing abortion once a fetal heartbeat could be detected (typically around the sixth or seventh week of pregnancy)); La. Sess. Law Serv. Act 620, H.B. 388, 40th Reg. Sess. (2014) (enacted) (requiring doctors who perform abortions to have admitting privileges to a hospital within 30 miles of their clinics). See also MKB Mgmt. Corp. v. Stenehjem, 795 F.3d 768 (8th Cir. 2015) (holding that North Dakota's statute impermissibly infringed on the right to choose to terminate pregnancy before viability); June Med. Servs. LLC v. Kliebert, 158 F. Supp. 3d 473 (M.D. La. 2016) (holding that Louisiana's statute placed an undue burden on a large percentage of women seeking an abortion, and thus was facially unconstitutional).

82. See, e.g., ALA. CODE § 26-23A-4(a) (Lexis through 2017 Sess.) (48-hour waiting period); ARIz. REv. STAT. ANN. § 36-2153 (Lexis through 2017 Sess.) (24-hour waiting period); ARK. CoDE ANN. § 20-16-1703 (Lexis through 2017 Sess.) (48-hour waiting period); GA. CODE ANN. § 31-9A3 (Lexis through 2017 Sess.) (24-hour waiting period); IDAHO CODE ANN. § 18-609 (Lexis through 2017 Sess.) (24-hour waiting period); IND. CODE ANN. § 16-34-2-1.1 (Lexis through 2017 Sess.) (18-hour waiting period); KAN. STAT. ANN. § 65-6709 (Lexis through 2017 Sess.) (24-hour waiting period); KY. REV. STAT. ANN. § 311.725 (Lexis through 2017 Sess.) (24-hour waiting period); LA. StAT. ANN. § 40:1299.35.6 (Lexis through 2017 Sess.) (24-hour waiting period); Мich. СомP. LAWs § 333.17015 (Lexis through 2017 Sess.) (24-hour waiting period); MinN. STAT. § 145.4242 (Lexis through 2017 Sess.) (24-hour waiting period); Miss. CoDE. ANN. § 41-41-33 (Lexis through 2017 Sess.) (24-hour waiting period); Mo. REV. STAT. § 188.027 (Lexis through 2017 Sess.) (72hour waiting period); NEB. REV. STAT. ANN. § 28-327 (Lexis through 2017 Sess.) (24-hour waiting period); N.C. GEN. STAT. § 90-21.82 (Lexis through 2017 Sess.) (72-hour waiting period); N.D. CENT. CODE § 14-02.1-03 (Lexis through 2017 Sess.) (24-hour waiting period); OKLA. STAT. ANN. tit. 63, § 1-738.2 (Lexis through 2017 Sess.) (72-hour waiting period); 18 PA. CoNs. STAT. § 3205 (Lexis through 2017 Sess.) (24-hour waiting period); S.C. CODE ANN. § 44-41-330 (Lexis through 2017 Sess.) (24-hour waiting period); S.D. CoDIFIED LAWs § 34-23A-56 (Lexis through 2017 Sess.) (72-hour waiting period); TENN. CODE ANN. § 39-15-202(d)(1) (Lexis through 2017 Sess.) (48-hour waiting period); TEX. HEALTH AND SAFETy CODE ANN. § 171.012 (Lexis through 2017 Sess.) (24hour waiting period); UTAH CODE ANN. § 76-7-305 (Lexis through 2017 Sess.) (72-hour waiting period); VA. CODE ANN. § 18.2-76 (Lexis through 2017 Sess.) (24-hour waiting period); W. VA. CODE ANN. § 16-2I-2 (Lexis through 2017 Sess.) (24-hour waiting period); WIS. STAT. ANN. § 253.10 (Lexis through 2017 Sess.) (24-hour waiting period).

83. See, e.g., Ala. CodE § 26-21-3 (Lexis through 2017 Sess.); Alaska Stat. AnN. § 18.16.020 (Lexis through 2017 Sess.); ARIZ. REV. STAT. ANN. § 36-2152 (Lexis through 2017 
oral description of the ultrasound image, ${ }^{84}$ and mandatory provision of information about alternatives to abortion. ${ }^{85}$ Additionally, several states have recently attempted to diminish access to abortion by imposing stringent requirements on providers, such as requiring that abortion doctors have admitting privileges at hospitals within 30 miles of the abortion facility ${ }^{86}$ and requiring that abortion facilities meet the standards for ambulatory surgical centers. ${ }^{87}$ The U.S. Supreme Court

Sess.); ARK. Code AnN. § 20-16-804 (Lexis through 2017 Sess.); Colo. Rev. StAT. AnN. § 1237.5-104 (Lexis through 2017 Sess.); DEL. CODE ANN. tit. 24, § 1783 (Lexis through 2017 Sess.); Fla. STAT. AnN. § 390.01114 (Lexis through 2017 Sess.); GA. CodE ANN. § 15-11-682 (Lexis through 2017 Sess.); IDAHO CODE ANN. § 18-609A (Lexis through 2017 Sess.); 750 ILL. Comp. STAT. ANN. 70/15 (Lexis through 2017 Sess.); IND. CODE ANN. § 16-34-2-4 (Lexis through 2017 Sess.); IowA CODE ANN. § 135L.3 (Lexis through 2017 Sess.); KAN. STAT. ANN. § 65-6704 (Lexis through 2017 Sess.); Ky. REV. STAT. AnN. § 311.732 (Lexis through 2017 Sess.); LA. STAT. ANN. § 40:1061.14 (Lexis through 2017 Sess.); MD. CODE ANN., HEALth-GEN. § 20-103 (Lexis through 2017 Sess.); Mass. Gen. Laws ANN. ch. 112, § 12S (Lexis through 2017 Sess.); Mich. Comp. LAWS ANN. § 722.903 (Lexis through 2017 Sess.); MinN. STAT. ANN. § 144.343 (Lexis through 2017 Sess.); Miss. CodE. ANN. § 41-41-53 (Lexis through 2017 Sess.); Mo. ANN. STAT. § 188.028 (Lexis through 2017 Sess.); Neb. Rev. Stat. AnN. § 28-327.09 (Lexis through 2017 Sess.); N.H. Rev. Stat. AnN. § 132:33 (Lexis through 2017 Sess.); N.C. Gen. Stat. AnN. § 90-21.7 (Lexis through 2017 Sess.); N.D. CENT. CODE ANN. § 14-02.1-03.1 (Lexis through 2017 Sess.); OHIO ReV. Code ANN. § 2919.12 (Lexis through 2017 Sess.); OKLA. STAT. AnN. tit. 63, § 1-740.2 (Lexis through 2017 Sess.); 18 PA. STAT. AND CONS. STAT. ANN. § 3206 (Lexis through 2017 Sess.); 23 R.I. GEN. LAWS ANN. § 23-4.7-6 (Lexis through 2017 Sess.); S.C. CODE ANN. § 44-41-31 (Lexis through 2017 Sess.); S.D. Codified LAws § 34-23A-7 (Lexis through 2017 Sess.); TENN. CodE ANN. § 37-10-303 (Lexis through 2017 Sess.); TeX. FAM. CoDE ANN. § 33.002 (Lexis through 2017 Sess.); UtAH CodE ANN. § 76-7-304.5 (Lexis through 2017 Sess.); VA. CODE ANN. § 16.1-241 (Lexis through 2017 Sess.); W. VA. CodE ANN. § 16-2F-3 (Lexis through 2017 Sess.); WIS. STAT. ANN. § 48.375 (Lexis through 2017 Sess.); Wyo. STAT. ANN. § 35-6-118 (Lexis through 2017 Sess.).

84. See, e.g., ALA. CoDE §§ 26-23A-4(4), (5); 26-23A-6 (b), (c) (Lexis through 2017 Sess.); ARIZ. Rev. STAT. §§ 36-2151; 36-2156 (Lexis through 2017 Sess.); Fla. STAT. ANN. §§ 390.0111(3)(a)1.b.(I) through (3)(a)1.b.(IV) (Lexis through 2013 Sess.); Ky. REV. STAT. ANN. §§ 311.710 to 311.820 (Lexis through 2017 Sess.); LA. STAT. ANN. § 40:1299.35.2(D) (Lexis through 2013 Sess.); Miss. Code AnN. § 41-41-34 (Lexis through 2013 Sess.); Tex. HeAlth \& SAFETY CODE $\S \S 171.012 ; 171.0122$ (Lexis through 2013 Sess.); VA. CODE ANN. § 18.2-76 (B);(C);(D)(4);(D)(5);(F)(1) (Lexis through 2013 Sess.); Wis. STAT. ANN. § 253.10 (3g) (Lexis through 2012 Sess.).

85. See, e.g., AlA. CODE § 26-23A-4(a) (Lexis through 2017 Sess.); Ariz. REv. StAt. AnN. § 36-2153 (Lexis through 2017 Sess.); ARK. CODE ANN. § 20-16-810 (Lexis through 2017 Sess.); IND. CoDE ANN. § 16-34-2-1.1 (Lexis through 2017 Sess.); KAN. STAT. ANN. § 65-6704 (Lexis through 2017 Sess.); Ky. ReV. StAT. AnN. § 311.725 (Lexis through 2017 Sess.); LA. REV. STAT. ANN. § 40:1299.35.6 (Lexis through 2017 Sess.); MASS. GEN. LAWS ANN. ch. 112, § 12S (Lexis through 2017 Sess.); Miss. CODE. ANN. § 41-41-33 (Lexis through 2017 Sess.); Mo. ANN. STAT. § 188.027 (Lexis through 2017 Sess.); OKLA. STAT. ANN. tit. 63, § 1-738.2 (Lexis through 2017 Sess.); 18 Pa. Stat. AND Cons. STAT. ANN. § 3205 (Lexis through 2017 Sess.); UTAH CodE ANN. § 76-7-305.5 (Lexis through 2017 Sess.); WIS. STAT. ANN. § 253.10 (Lexis through 2017 Sess.).

86. See, e.g., TEX. HEALTH \& SAFETY CODE ANN. §171.0031(a) (Lexis through 2015 Sess.).

87. See, e.g., TEX. HEALTH \& SAFETY CODE ANN. \$245.010(a) (Lexis through 2017 Sess.). 
ruled on June 27, 2016 that such requirements "place[] a substantial obstacle in the path of women seeking a previability abortion, each constitutes an undue burden on abortion access, and each violates the Federal Constitution." 88

Many of the restrictions that U.S. states impose on women seeking abortions run afoul of accepted international human rights norms. In 2011, the U.N. Special Rapporteur on the Right of Everyone to the Enjoyment of the Highest Attainable Standard of Physical and Mental Health listed a number of abortion restrictions found throughout the world. Among these restrictions are "laws prohibiting public funding of abortion care; requirements of counselling and mandatory waiting periods for women seeking to terminate a pregnancy; ... . [and] parental and spousal consent requirements." ${ }^{89}$ The report stated that "[t]hese laws make safe abortions... unavailable, especially to poor, displaced and young women." 90 As discussed below, however, opponents of abortion believe that they are protecting the human rights of unborn humans, and that laws and norms failing to recognize the unborn as humans are fundamentally flawed.

\section{B. Rationale Supporting Restrictions on Access to Abortion: Life Begins at Conception}

Persons who oppose abortion hold the unshakeable belief that terminating human life at any stage of development, beginning with fertilization of the ovum, is morally wrong and a gross violation of human rights. ${ }^{91}$ The anti-abortion movement in the United States is thus defined by the core belief that life begins at conception. As expressed by the National Right to Life Committee, “[t]he only reasonable perspective is that every human being's life must be protected from the moment of fertilization until natural death." 92 Similarly, the American Association of Pro-Life Obstetricians and Gynecologists states that "the unborn child

88. Whole Woman’s Health v. Hellerstedt, 136 S. Ct. 2292, 2300 (2016)

89. Interim report of the Special Rapporteur on the right of everyone to the enjoyment of the highest attainable standard of physical and mental health, supra note 22.

90. Id.

91. See, e.g., Human Life and Dignity, U.S. Conf. OF CATHOLIC Bishops, http://www.usccb.org/issues-and-action/human-life-and-dignity/index.cfm [https://perma.cc/PZ3KKCPJ]. ("[E]very human life is sacred from conception to natural death.”).

92. Olivia Gans Turner \& Mary Spaulding Balch, When They Say ... You Say: Defending the Pro-Life Position \& Framing the Issue by the Language We Use, NATIONAL Right TO LifE Comm., (2014) at 12, http://www.nrlc.org/uploads/WhenTheySayPacket.pdf [https://perma.cc/6HE6-PAH7]. 
is a human being from the time of fertilization." ${ }^{93}$ Myriad other antiabortion organizations voice the same core belief. ${ }^{94}$

One of the most fascinating aspects of the abortion debate is the related debate over whether that core belief is religious. It clearly is a belief grounded in religious convictions for explicitly religious groups, such as the U.S. Conference of Catholic Bishops, whose members oppose abortion because they believe all life is a gift from God, ${ }^{95}$ and the Christian Medical and Dental Association, whose members oppose abortion as "contrary to respect for the sanctity of human life, as taught in the revealed, written Word of God." 96 Other groups, however, avoid any mention of God or religion and instead mention the dignity and value of each individual life. ${ }^{97}$

Court filings from anti-abortion groups also dispute that the belief that life begins at conception is necessarily religious, or the filings avoid any mention of religion altogether. The primary focus of anti-abortion legal action tends to be, purportedly, concern for the health and safety of women. For example, an amicus brief filed by several religiouslyaffiliated medical associations raised the following arguments in support of a Texas law restricting the administration of an oral early-abortion drug commonly known as RU-486: "States have a legitimate interest in women's health from the outset of pregnancy;" "[s]tates have 'wide discretion' to regulate abortion when there is 'medical and scientific

93. Our Mission Statement, AMERICAN Association of Pro-Life OBSTETRICIANS AND GYNECOLOGISTS, http://www.aaplog.org/about-2/our-mission-statement/ [https://perma.cc/7XV2C4QJ].

94. See, e.g., Statement of Values, COLORADO RIGHT TO LIFE, http://www.coloradorighttolife.org/statement-values [https://perma.cc/43XQ-MGWJ] ("Every human being has a God-given right to life from the beginning of that person's biological development through natural death, regardless of their perceived value to society.”); Who We Are, TEXAS RIGHT TO LIFE, https://www.texasrighttolife.com/who-we-are/ [https://perma.cc/BHS35HTG] ("[E]ach human being, from the moment of fertilization until natural death, has an immeasurable dignity and inalienable Right to Life."); The Mission and Vision of Wisconsin Right to Life, WisCONSIN RIGHT TO LIFE, http://wrtl.org/mission/ ("[E]ach human life is inherently valuable from fertilization to natural death.”).

95. U.S. CONF. OF CATHOLIC BISHOPS, supra note 91.

96. Abortion Ethics Statement, CHRISTIAN MEDICAL AND DENTAL Association, https://cmda.org/resources/publication/abortion-ethics-statement [https://perma.cc/2UHR-XMQH.

97. See, e.g., About Us, AMERICAN Association of Pro-Life Obstetricians AND GYNECOLOGISTS, http://www.aaplog.org/about-us/ [https://perma.cc/W5EZ-NR54] (“[P]urpose is to reaffirm the unique value and dignity of individual human life in all stages of growth and development from fertilization onward.”); National Right to Life Mission Statement, NATIONAL RIGHT TO LIFE, http://www.nrlc.org/about/mission/ [https://perma.cc/G2B5-UMP7] ("National Right to Life carries out its lifesaving mission by promoting respect for the worth and dignity of every individual human being, born or unborn, including unborn children from their beginning.”). 
uncertainty;"” and "[s]afety and medical data support ... the 'wide discretion' of the Texas Legislature." 98

It is perhaps perplexing at first glance that groups that hold strong religious beliefs would avoid couching their opposition to abortion in religious terms. But the motivation for avoiding any mention of religious convictions becomes clear when viewed in the context of constitutionally-protected religious freedom. ${ }^{99}$ If the parlance of the antiabortion movement is "abortion is a crime against God and humanity according to my religion," then members of that religion are using secular legislatures to impose their beliefs on others in contravention of the First Amendment. ${ }^{100}$ As one religious group stated in its amicus brief supporting abortion rights, "[d]efining human life as beginning from the moment of conception places the state's imprimatur upon a particular religious belief, in an area that has been the subject of considerable theological and doctrinal dispute.” 101

Regardless of the legal reasons why anti-abortion groups often avoid mention of religious convictions, there is little doubt that belief in life from the moment of conception is primarily a religious one. ${ }^{102}$ The debate, however, often transcends religion. For some who espouse an anti-choice perspective, it is not a religious question but rather one of human rights. Some atheists and secularists share the belief, from a humanist perspective, that embryos and fetuses are human beings who should be protected just as any vulnerable human being should be protected from violence. ${ }^{103}$ Similarly, many people identify as members

98. Brief for American Association of Pro-Life Obstetricians \& Gynecologists, Christian Medical Association, Catholic Medical Association, Physicians for Life, National Association of Pro Life Nurses, National Association of Catholic Nurses, and The National Catholic Bioethics Center as Amici Curiae Supporting Defendants-Appellants, Planned Parenthood of Greater Tex. Surgical Health Servs. v. Abbott, 748 F.3d 583 (5th Cir. 2014), (No. 13-51008).

99. See Lee, supra note 1, at 343 (asserting that the right to freedom of religion would be seriously impinged upon if a particular religious teaching should be transformed into secular law and therefore binding on the entire population, including other religious or nonreligious groups).

100. See, e.g., John Morton Cummings, Jr., Comment, The State, the Stork, and the Wall: The Establishment Clause and Statutory Abortion Regulation, 39 CATH. U. L. REV. 1191, 1193 (1990) (“[Antiabortion] statutes lack a secular purpose, benefit specific religious organizations, unnecessarily entangle church and state, and place the state on one side of a political issue which is divided along religious lines, thus violating the establishment clause.”).

101. Brief for Agudath Israel of America as Amici Curiae Supporting Petitioners, Webster v. Reprod. Health Servs., 492 U.S. 490 (1989) (No. 88-605), at 4.

102. See Hernandez, supra note 37, at 347 (citing P. SACHDEv, InTERNATIONAL HANDBOOK ON ABORTION 3 (1988)) ("In the Western world, prohibition of abortion was based on religious grounds: the Catholic Church's condemnation of abortion or any form of contraception.”).

103. See, e.g., Human Being, SECULAR PROLIFE, http://www.secularprolife.org/ \#!abortion/cimp [https://perma.cc/M2A9-DG77] (stating that members believe, absent or regardless 
of religions that are against abortion, such as Catholicism, but nevertheless personally support individual choice on the matter of abortion. ${ }^{104}$

Given the existence of both secular and religious viewpoints that life begins at conception and that human beings should have the right to life at all stages of development, as well as individual deviation from the official teachings of various churches on abortion, it is clear that the argument transcends religion. It is also fair to say that the question, while not always religious, is nevertheless a profoundly personal one, given the wide disparity of views on abortion. Even anti-abortion groups concede that at least $50 \%$ of Americans believe abortion should be legal. ${ }^{105}$

In light of the fact that at least half of the U.S. population opposes abortion, one might imagine that means of preventing unwanted pregnancy, namely contraception and sex education, would be widely accessible and viewed favorably. In actuality, the reverse is true. As discussed below, the predominantly religious underpinnings of the anti-

of any religious beliefs, that because embryos and fetuses are human beings, and that it is universally accepted that killing human beings is wrong, it is wrong to kill unborn human beings); About Pro-Life Humanists, PRO-LIFE HuMANISTS, http://www.prolifehumanists.org/ (“[O]ppose discrimination against biological humans on the grounds of what they look like and how they function, and we believe that abortion should be rejected on the same ground as racism, sexism and ableism - which place greater importance on what the human entity does and looks like, than on what the entity in question actually is.”).

104. See, e.g., Brief for Religious Coalition for Reproductive Choice, 53 other religious organizations and religiously affiliated organizations, and fourteen clergy and laypersons as Amici Curiae Supporting Respondent, Stenberg v. Carhart, 530 U.S. 914 (2000) (No. 99-830), at 10, n.4 (internal citations omitted):

Some Roman Catholics, however, have explored and advocated religious views that would tolerate abortion under some circumstances. One Catholic organization has recently stated that there "is much in the Catholic tradition that supports the pro-choice position. [A] careful reading of church documents shows that while the prohibition of abortion is a serious teaching, room remains for Catholics to support the legalization of abortion and even its morality in a wide range of circumstances . ..." According to a recent poll, eighty-two percent of Catholics in this country believe that abortion should be legal either under certain circumstances or without restrictions. Moreover, thirty-nine percent believe that a woman should be able to decide to have an abortion no matter what the reason. Only fifteen percent of Catholics believe that abortion should be illegal in all circumstances.

105. See Secular Pro-Life, Anti-abortion is not anti-woman, available at http://www.secularprolife.org/\#!pro-woman/c14bx [https://perma.cc/JZ72-B5KJ] ("There's little difference between the number of men and number of women who call themselves 'pro-life' (roughly half of Americans), and there's also little difference between the number of men and number of women who believe abortion should generally be illegal (again, roughly half of Americans) - and these trends have held for years.”). 
abortion movement pervade many other aspects of sexual health and family planning.

\section{Beyond the Rationale: Religion- and Conscience-Based Restrictions on Access to Contraception and Sex Education Impede Protection of Prenatal Life}

Conscience- or religion-based restrictions on abortion are exacerbated in the United States by a lack of access to contraception and sex education. Many prominent anti-abortion groups also oppose sex before marriage, contraception, and comprehensive sex education. They and the lawmakers whom they support seek to defund Planned Parenthood ${ }^{106}$ (the largest provider of reproductive health services in the United States ${ }^{107}$ and promote abstinence-only sex education. As a result, in part of these efforts, an estimated 20 million women at risk of an unwanted pregnancy in the United States required publicly-funded contraceptive services in $2014,{ }^{108}$ but only $39 \%$ of those women received it, ${ }^{109}$ down from $47 \%$ in $2010 .{ }^{110}$

American women also faced a lack of access to contraception by pharmacists who refused to dispense lawfully prescribed contraception because of their religious or moral beliefs. ${ }^{111}$ Several states explicitly allow pharmacists to refuse to dispense medication on religious or moral

106. See Babor, supra note 8, at 90 ("[In 1984] the Reagan administration forged an alliance with the Catholic Church to withdraw funding from both the United Nations Population Fund and the International Planned Parenthood Federation.”).

107. See William P. Barrett, The Largest U.S. Charities For 2016, ForBES (Dec. 14, 2016), https://www.forbes.com/companies/planned-parenthood-federation-of-america/ [https://perma.cc/KT8M-VT3W].

108. Fact Sheet: Publicly Funded Family Planning Services in the United States, GUTTMACHER INST. (2016) at 1, https://www.guttmacher.org/fact-sheet/publicly-funded-familyplanning-services-united-states [https://perma.cc/W68J-BZ6E]. Those who were eligible "either had an income below $250 \%$ of the federal poverty level or were younger than 20 .” Id.

109. Id. at 2.

110. Jennifer J. Frost, Mia R. Zolna \& Lori Frohwirth, Contraceptive Needs and Services, 2010, GUTTMACHER INST. (July 2013), at 14, https://www.guttmacher.org/sites/default/ files/report_pdf/contraceptive-needs-2010.pdf [https://perma.cc/NMX7-ULHF].

111. See State Policies in Brief: Refusing to Provide Health Services, GutTMACHER Inst., (Mar. 1, 2016), https://www.guttmacher.org/state-policy/explore/refusing-provide-health-services [https://perma.cc/2HQ9-X3TA] (charting the "conscience" laws of each state and the District of Columbia). See also Abigail S. Kurland, Access to Contraception, 7 GEO. J. GENDER \& L. 1129 (2006) (" $[\mathrm{C}]$ ases of women being denied their prescriptions have emerged across the nation .... A health care provider's unilateral decision to deny a woman access to a legal and valid prescription for emergency contraception has a potentially tangible and devastating and real impact upon a woman's health and reproductive choices"). 
grounds. ${ }^{112}$ Several other states have broad refusal clauses that could be interpreted as giving pharmacists the right to refuse to dispense contraception on religious or moral grounds. ${ }^{113}$ There are also federal statutes stating the same: that if religious beliefs or moral convictions conflict, the provider does not have to participate in the federally-funded program. ${ }^{114}$ Controversial regulations promulgated by the Department of Health and Human Services in 2008 during the Bush presidency ${ }^{115}$ (and repealed in 2011 by the Obama administration ${ }^{116}$ ) seemed to expand the reach of the laws. The Department's response to comments, for example, unequivocally stated that access to contraception would be impacted in

112. See ARK. CODE ANN. § 20-16-304(4) (Lexis through 2009 Sess.) (permitting pharmacists to refuse to dispense contraception); COLO. REV. STAT. § 25-6-102 (Lexis through 2017 Sess.) (permitting pharmacists to refuse to "provide contraceptive procedures, supplies, and information when such refusal is based upon religious or conscientious objection”); FLA. STAT. § 381.0051(5) (Lexis through 2017 Sess.) (permitting pharmacists to refuse "to furnish any contraceptive or family planning service, supplies, or information for medical or religious reasons."); ME. REV. STAT. tit. 22, § 1903 (Lexis through 2017 Sess.) (permitting pharmacists to refuse "to provide family planning services when such refusal is based upon religious or conscientious objection.”); TENN. CODE ANN. $\S$ 68-34-104 (Lexis through 2017 Sess.) (permitting pharmacists to refuse "to provide contraceptive procedures, supplies, and information when such refusal is based upon religious or conscientious objection ....”).

113. See ARIZ. Rev. Stat. ANN. § 36-2154(B) (Lexis through 2009 Sess.) (permitting pharmacists to refuse to dispense any drug or device intended to inhibit or prevent implantation of a fertilized ovum); GA Comp. R. \& REgS. 480-5-.03 (Lexis through 2009 Sess.) ("It shall not be considered unprofessional conduct for any pharmacist to refuse to fill any prescription based on his/her professional judgment or ethical or moral beliefs.”); IDAHO CODE § 18-611 (Lexis through 2010 Sess.) (permitting pharmacists to refuse to dispense emergency contraception); IDAHO CODE $\S$ 18-611(4) (Lexis through 2017 Sess.) ("No health care professional or employer of the health care professional shall be civilly, criminally or administratively liable for the health care professional declining to provide health care services that violate his or her conscience”); MISS. CODE. ANN. § 41-41-215 (Lexis through 2017 Sess.) (permitting pharmacists to "decline to comply with an individual instruction or health-care decision for reasons of conscience.”); S.D. CODIFIED LAws $\S$ 36-11-70 (Lexis through 2009 Sess.) (permitting pharmacists to refuse to dispense any medication if there is reason to believe that the medication would be used to cause an abortion or destroy an unborn child, defined as "an individual organism of the species homo sapiens from fertilization until live birth").

114. 42 U.S.C.A. § 300a-7 (Lexis through 2017 Sess.); See also The Public Health Service Act, 42 U.S.C. 238n at sec. 245, and the Weldon Amendment, Consolidated Appropriations Act, 2008, Pub. L. No. 110-161, Div. G, § 508(d), 121 Stat. 1844, 2209 (2007) (collectively referred to as the federal healthcare conscience protection statutes).

115. Ensuring That Department of Health and Human Services Funds Do Not Support Coercive or Discriminatory Policies or Practices in Violation of Federal Law, 73 Fed. Reg. 7807201 (Dec. 19, 2008) (to be codified at 45 C.F.R. pt. 88).

116. Regulation for the Enforcement of Federal Health Care Provider Conscience Protection Laws, 76 Fed. Reg. 9968-02 (Feb. 23, 2011) (to be codified at 45 C.F.R. pt. 88). 
situations where "those contraceptives are currently delivered over the religious or moral objections of the provider."117

Another means of preventing unwanted pregnancy and related abortions is through comprehensive sex education. ${ }^{118}$ But the content and effectiveness of sex education in schools varies state by state. Only half the states mandate sex education. ${ }^{119}$ Thirty-six states allow parents to remove their children from sex education classes. ${ }^{120}$ Only 13 states require that the information provided in sex education classes be medically accurate. ${ }^{121}$ Twenty-six states require that abstinence be stressed, ${ }^{122}$ often "through highly restrictive programs that ignore or often actively denigrate the effectiveness of contraceptives and safer-sex behaviors." 123

To the extent that limitations on access to contraception and effective sex education are the result of religious and moral beliefs about proper sexuality, the goal appears to be to coerce adherence to those religious and moral beliefs, even when doing so increases the chances of unwanted pregnancies, and consequently, abortions. When lack of access to pregnancy prevention methods exists alongside lack of access to abortion, the result is coerced child-bearing. As the discussion below aims to highlight, reproductive coercion — even when imposed ostensibly for the good of society-can have severe negative consequences and may constitute a human rights violation.

117. Ensuring That Department of Health and Human Services Funds Do Not Support Coercive or Discriminatory Policies or Practices in Violation of Federal Law, 73 Fed. Reg. 7808182 (Dec. 19, 2008) (to be codified at 45 C.F.R. pt. 88); id.

118. See Douglas Kirby, Emerging Answers 2007: Research Findings on Programs to Reduce Teen Pregnancy and Sexually Transmitted Diseases, The National Campaign to PreVent Teen AND UnPlanNed PREgNANCY (2007), at 108, https://thenationalcampaign.org/ sites/default/files/resource-primary-download/EA2007_full_0.pdf [https://perma.cc/J97U-U6Y4] ("[A] substantial percentage of abstinence, sex, and STD/HIV education programs significantly reduced one or more types of risky sexual behavior.”).

119. State Policies in Brief: Sex and HIV Education, GuTTMACHER InST. (Mar. 2016) at 1, https://www.guttmacher.org/state-policy/explore/sex-and-hiv-education [https://perma.cc/DZ7T$7 \mathrm{XNV}]$.

120. Id.

121. Id.

122. Id. at 2.

123. Heather D. Boonstra, Advocates Call for a New Approach After the Era of "AbstinenceOnly” Sex Education, 12 GuTTMACher Pol. ReV. 6 (2009). See, e.g., 42 U.S.C. § 710(b)(2) (requiring states receiving federal abstinence-only funds to teach "that a mutually faithful monogamous relationship in context of marriage is the expected standard of human sexual activity" and that "sexual activity outside of the context of marriage is likely to have harmful psychological and physical effects"). 


\section{CHINA'S POPULATION CONTROL LAW AND POLICIES: REPRODUCTIVE FREEDOM VS. SUSTAINABILITY}

\section{A. China's Population Control Law and Policies}

China has vigorously promoted contraception and population control since the 1960s. ${ }^{124}$ Encouraged by the success of early voluntary programs and urged by population "hawks" concerned about the "inexorable momentum of continued population growth," ${ }^{25}$ China adopted a strict population control policy in $1979 .{ }^{126}$ The policy was codified in 2001 with the stated purpose of carrying on the "current policy for reproduction, encouraging late marriage and childbearing and advocating one child per couple.”127 The law authorizes a number of rewards for families that abide by it. ${ }^{128}$ The only penalty specifically authorized by the law is a fine, called a "social maintenance fee." ${ }^{129}$ The law specifically states that "the people's governments at all levels and their staff members shall perform their administrative duties strictly in accordance with law, and enforce the law in a civil manner, and they may not infringe upon legitimate rights and interests of citizens.”130

China has officially revised the law twice. In 2014, China allowed families to apply to have a second child if one of the parents was an only child. ${ }^{131}$ In January 2016, China replaced the one-child policy with a two-child policy. ${ }^{132}$ These changes are intended to respond to concerns about China's aging population and the potential demographic crisis and

124. Barry Naughton, The Chinese ECONOMY: TRAnsitions AND Growth 167-68 (Kourtney Heinz, ed., 1st ed. 2007).

125. Id. at 168 .

126. XiaOBING Li, Civil LiBerties in China 102 (Kaitlin Ciarmiello, ed., 1st ed. 2010).

127. Population and Family Planning Law of the People's Republic of China (Order of the President No. 63) (adopted at the 25th Meeting of the Standing Comm. Nat'l People's Cong. Dec. 29, 2001, effective Sept. 1, 2002), art. 18, 2010 P.R.C. LAws (China), http://www.gov.cn/english/laws/2005-10/11/content_75954.htm [https://perma.cc/J3NR-CHUM].

128. Id. at art. 23-29.

129. Id. at art. 41.

130. Id. at art. 4.

131. Jonathan Kaiman, China's One-Child Policy to be Relaxed as Part of Reforms Package, THE GuARDiAn (Nov. 15, 2013), https://www.theguardian.com/world/2013/nov/15/china-one-childpolicy-relaxed-reforms [https://perma.cc/RNH5-7LE5].

132. Laurie Burkitt, China Delivers on Two-Child Birth Policy, Wall Street J. (Dec. 27, 2015), $\quad$ https://www.wsj.com/articles/china-delivers-on-two-child-birth-policy-1451215976 [https://perma.cc/843V-T6N7]. 
concomitant slowdown in economic growth that will occur if China does not increase its working-age population. ${ }^{133}$

The government has enforced the policy with a carrot and stick approach, providing wide access to contraception, financial incentives, and preferred access to daycare and schools for compliant couples, and inflicting fines, forced abortion, and forced sterilization on noncompliant couples. ${ }^{134}$ While the government has permitted various exceptions, at least $36 \%$ of China's citizens have been prohibited from having more than one child. ${ }^{135}$

Despite the relatively innocuous wording of the 2001 law and its specific admonition that the law be enforced in a civil manner, the law and its preceding policy have become synonymous with forced and coerced abortion, forced and coerced sterilization, debilitating fines, and other severe penalties, such as confiscation of belongings and destruction of offenders' houses. ${ }^{136}$ The law delegates the implementation of the population control policy to "governments of townships, ethnic townships, and towns, and neighborhood offices in urban areas," ${ }^{37}$ which had been responsible for population control since the policy came into effect in 1979. ${ }^{138}$ Moreover, and perhaps more tellingly, the law contains language suggesting that failure is not an option: "Villagers' committees and residents' committees shall, in accordance with law, make a success of the family planning programs. Government departments, the armed forces, public organizations,

133. G.E., Why is China Relaxing its One-Child Policy?, THE ECONOMIST (Dec. 10, 2013), https://www.economist.com/blogs/economist-explains/2013/12/economist-explains-8 [https://perma.cc/P832-AHMF].

134. Naughton, supra note 124, at 169-70.

135. Charles F. Bingman, China's Population Bomb, 7 J. OF THE WASHINGTON INST. OF CHINA STUDIES 1 (Sept. 2012), https://www.bpastudies.org/bpastudies/article/view/174/329 [https://perma.cc/BDF8-SPEP].

136. Naughton, supra note 124, at 169-70.

137. Population and Family Planning Law of the People’s Republic of China, supra note 127, at art. 10 .

138. See Max Fisher, Why China's One-Child Policy Still Leads to Forced Abortions, and Always Will, WASH. POST (Nov. 15, 2013), https://www.washingtonpost.com/ news/worldviews/wp/2013/11/15/why-chinas-one-child-policy-still-leads-to-forced-abortions-andalways-will/?utm_term=.8eda8ce2d04b [https://perma.cc/6A8H-YZLJ]:

The senior leadership in Beijing may set national policy... but it's local- and provincial-level officials who choose when, whether and how to actually enforce those policies. If those mid-level officials want to do things differently - say . . . by continuing to use forced abortions to control birthrates, even though Beijing banned that years ago- they often do. 
enterprises and institutions shall make a success of the family planning programs in their own units." 139

The strictness with which the population control policy has been enforced has fluctuated since its introduction in $1979 .{ }^{140}$ In its first five years, enforcement was strict and often brutal. Enforcement measures included "insertion of intrauterine devices (IUDs) for women who already had one child, sterilization for couples with two or more children, and abortion for unauthorized conceptions." ${ }^{141}$ Domestic and international criticism of these extreme measures led to a relaxing of the policy, but "local officials [were] under substantial top-down pressure to control births, and they sometimes resort[ed] to actions that contravene[d] declared central government policy, such as coercive sterilization or abortion.” 142

Enforcement has also varied by region, due to the central government delegating population control to local governments, but also due to exceptions granted to certain groups. For example, regions heavily populated by ethnic minorities have a higher birth rate due to the exemption of ethnic minorities from the population control policy. ${ }^{143}$ Local governments in some rural areas allow couples whose first child is a girl to have a second child, ${ }^{144}$ bowing to a deeply embedded cultural and religious preference for male children. ${ }^{145}$ In contrast, women in urban areas are subject to intrusive monitoring of their fertility cycles by their workplaces. ${ }^{146}$

China has been, and despite the revisions to the policy, continues to be the subject of much criticism for its coercive population control

139. Population and Family Planning Law of the People’s Republic of China, supra note 127, at art. 12. See also Forced Abortion and Sterilization in China: The View from Inside: Hearing Before the Subcommittee of International Operations and Human Rights of the Comm. on International Relations, House of Representatives, 105th Cong. 2d Sess. 22, at 19 (1998) (statement of Gao Xiao Duan, Planned Birth officer) (“[P]lanned birth cadres are responsible for their villages and, to avoid being criticized and punished by their superiors - there's a very strict system of encouragement and punishment- they will resort to anything to achieve planned birth goals set by their superiors.").

140. See, Amy Hampton, supra note 7, at 329-33, 358-59 (for a concise and thorough history of the one-child policy).

141. Naughton, supra note 124, at 169.

142. Id.

143. Li, supra note 126, at 104.

144. Naughton, supra note 124 , at 169.

145. Li, supra note 126, at 106.

146. See Tara A. Gellman, The Blurred Line Between Aiding Progress and Sanctioning Abuse: United States Appropriations, the Unfpa and Family Planning in the P.R.C., 17 N.Y.L. SCH. J. HuM. RTS. 1063, 1067 (2001) (detailing intrusive methods of monitoring women's fertility, including workplaces publicly charting female employees' menstrual cycles). 
methods. ${ }^{147}$ There is little indication that the authorities responsible for enforcing the government's population control goals will cease resorting to the brutal methods discussed above. ${ }^{148}$ Unmarried women are still prohibited from having children. ${ }^{149}$

China nevertheless continues to stand by its attempts to monitor and control reproduction. Its purported goals are "bringing about a coordinated development between population on the one side and the economy, society, resources and environment on the other, promoting family planning, protecting the legitimate rights and interests of citizens, enhancing happiness of families, and contributing to prosperity of the nation and progress of the society." 150 The rationale for its strict population control policy, as well as the criticism it has faced and the negative consequences for which it is responsible, are discussed below.

\section{B. Rationale Supporting Coercive Population Control: Excessive Population Growth Impedes Development and Threatens Sustainability}

Prior to the campaign to control the population that began in the 1960s, China had experienced the exact opposite urging during the presidency of Mao Zedong. Mao supported unfettered reproduction and high birth rates, believing that a large population would improve productivity and otherwise benefit the nation. ${ }^{151}$ The government

147. See, e.g., China: Reform of One-Child Policy Not Enough, AmnESTy InTERnational (Oct. 29, 2015), https://www.amnesty.org/en/latest/news/2015/10/china-one-child-reform/ [https://perma.cc/BP3E-M6G9], ("Chinese women will remain at risk of intrusive forms of contraception and coerced or forced abortions ....”).

148. Id. (stating that Amnesty International has continued to receive reports of coerced abortions — which are technically illegal—and sterilizations in China).

149. See Yuan Ren, China's New Two-Child Policy Will Only Help Married Women. Single Mums Can Forget It, THE TELEgRAPH (Jan. 2, 2016), https://web.archive.org/web/20160102101651/http://www.telegraph.co.uk/women/life/chinas-newtwo-child-policy-will-only-help-married-women-single/ [https://perma.cc/W8KP-BTRK] (discussing the legal and cultural barriers preventing unmarried Chinese women from having children).

150. Population and Family Planning Law of the People’s Republic of China, supra note 127, at art. 1.

151. See John Franklin Copper, Franz H. Michael, \& Yuan-Li Wu, Human Rights in Post-Mao CHINA 30 (1985) (stating that Mao believed the possibility of over-population to be a "capitalist myth," and that "based on Marx's labor theory of value... a person's hands (in a situation of equal distribution under socialism) could produce more food than his mouth could eat; therefore, a population problem was impossible"). See also Laura Fitzpatrick, A Brief History of China's One-Child Policy, TIME (July 27, 2009), http://content.time.com/time/ 
condemned birth control and banned imports of contraceptives. ${ }^{152}$ Mao’s policies, designed to put China on a fast-track to modernization and industrialization, had disastrous consequences: the ensuing Great Famine killed 16.5 to 45 million people between 1959 and $1961 .{ }^{153}$ As a direct result of the Great Famine, China experienced soaring death rates and plummeting birth rates. ${ }^{154}$

China reversed course in the immediate aftermath of the Great Famine. Even while the birthrate rebounded when the famine ended, ${ }^{155}$ China's new policies sought to reduce the population and encourage small families through a system of incentives. ${ }^{156}$ By the time Deng Xiaoping assumed the presidency in 1978 and provided more access to the West, Professor Paul Ehrlich's book “The Population Bomb” ${ }^{157}$ had shaken the West with its dire predictions of an imminent unsustainable population explosion. ${ }^{158}$ Dr. Ehrlich warned that within a few years of the 1968 publication of his book, the world would undergo famines"hundreds of millions of people will starve to death in spite of any crash programs embarked upon now." 159 It is not clear whether or how much Dr. Ehrlich's book influenced the Deng government, but by 1979 population control had become a primary concern of the Chinese government.

Fear of widespread famine aside, China still has $18 \%$ of the world's population ${ }^{160}$ and only $7 \%$ of the world's arable land. ${ }^{161}$ Population

world/article/0,8599,1912861,00.html [https://perma.cc/Y3AM-C6X9] (quoting a top official of the Mao government: "A larger population means greater manpower. The force of 600 million liberated people is tens of thousands of times stronger than a nuclear explosion.”).

152. Aileen Clark, See How the One-Child Policy Changed China, NATIONAL GEOGRAPHIC (Nov. 13, 2015), http://news.nationalgeographic.com/2015/11/151113-datapoints-china-one-childpolicy/ [https://perma.cc/4TVD-SR5Q].

153. Xin Meng, Nancy Qian, \& Pierre Yared, The Institutional Causes of China's Great Famine, 1959-1961, 82 REV. ECONOMIC STUDIES 1568 (2015), https://www0.gsb.columbia.edu/ faculty/pyared/papers/famines.pdf [https://perma.cc/V6WE-3B3L].

154. Naughton, supra note 124, at 164.

155. Id. at 166.

156. Copper et al., supra note 151, at 30.

157. Paul R. Ehrlich, The Population Bomb (1968).

158. Nicholas D. Kristof, “China's Worst Policy Mistake”?, NEW YorK ReV. OF BOOKS (Apr. 7, 2016), http://www.nybooks.com/articles/2016/04/07/chinas-worst-policy-mistake/ [https://perma.cc/J9TR-QKMD].

159. Ehrlich, supra note 157, at xi.

160. U.N. Dep’t of Economic and Social Affairs, Population Division, World Population Prospects: The 2017 Revision, Key Findings and Advance Tables, U.N. Doc. ESA/P/WP/248 (2017) at 1.

161. Charlie Campbell, China May Not Have Enough Arable Land to Feed Its People. But Big Changes Are Coming, Time (Aug. 16, 2016), http://time.com/4455462/china-agriculture-foodsecurity/ [http://perma.cc/9H3T-CC3W]. 
control is therefore a principle mechanism towards achieving sustainable development. In its statement at the 2002 World Summit on Sustainable Development, China emphasized the connection between population and China's ability to realize its economic, environmental, and development goals: "We are still faced with considerable restraints and difficulties in implementing the sustainable development strategy due to our large population, low per capita resources, vulnerable ecology, uneven regional economic development, and inadequate development of our overall economy." 162 Scholars also recognize the connection between China's improved quality of life and its population control policies and find "the link... between rigorous population control and family planning measures, and economic growth" difficult to ignore. ${ }^{163}$ As a British medical journal article stated, "[t]he difference between a total fertility rate of 2.1, which might have been achieved without [China's] policy, and a total fertility rate of 1.6 (found today) releases $24 \%$ more resources for the family and national investment.”164

There are significant ideological problems with a law that severely curtails reproductive freedom, as well as significant practical problems with how China's law and policies have been carried out. Nevertheless, it is unlikely that China's rationale behind its coercive population control policy was to inflict misery on its citizens and flex its muscles by controlling an intimate aspect of its citizens' lives, but rather to improve its citizens' lives. ${ }^{165}$ Regardless of the government's intentions, however, the policy has had severe negative consequences that call into question the appropriateness of coercive population control policies. The

162. Statement by H.E. Mr. Zhu Rongji, Primier [sic] of the St. Council of the People's Republic of China, at the World Summit on Sustainable Development, Johannesburg, South Africa, CHINA-UN (Sept. 3, 2002) http://www.china-un.ch/eng/qtzz/wtojjwt/t85654.htm [https://perma.cc/WWB3-L9J6].

163. Carter Dillard, Prospective Parents and the Children's Rights Convention, 25 AM. U. INT’L L. REV. 485, 520 (2010).

164. Malcolm Potts, China's One Child Policy, 333 BRIT. MED. J. 361, 361 (2006) cited in Carter Dillard, supra note 163, at 529. But see Sen, supra note 38, at 1049-51 (disputing the urgent need for population control and arguing that development inevitably leads to lower fertility rates even absent coercion); Sen, supra note 38, at 1054-58 (comparing the more successful non-coercive fertility reduction of Kerala and other Indian states to China). For a rebuttal, see Potts at 361 ("The Indian economy has begun to grow rapidly, but unlike China the decline in fertility has been uneven, and states such as Bihar and Uttar Pradesh (total fertility rates of 4.4 and 4.8) remain mired in poverty.").

165. Babor, supra note 8, at 99, n. 60 ("In China, with its system of government and traditions based on collectivist principles, population control methods, such as the one child policy, are viewed as consistent with the cultural emphasis placed on duties to society over individual rights.”). 
policies are an indispensable component of the discussion of whether such policies are consistent with international human rights norms.

\section{Beyond the Rationale: China's Coercive Population Control Program Has Far Exceeded its Goals, Creating a Demographic Crisis and Inflicting Needless Brutality}

China's population control laws and policies have had severe negative consequences with respect to human rights and demographics. Various governments and human rights organizations have condemned the coercive population control program, questioning the legitimacy of a government interfering in such a personal matter and condemning the often brutal consequences of failing to comply with the policy. The condemnation has also covered the incidences of female infanticide and sex-selective abortion resulting from the policy. After three decades of standing firm against the criticism, China now faces two separate demographic crises: an aging population with too few people in the younger generations and a severe discrepancy between the number of males and females.

\section{Human Rights Violations: Forced Abortions, Stigmatized Children, and Disposal of Female Children}

The one-child policy has generated a number of human rights violations, including forced and coerced abortions, forced and coerced sterilizations, stigmatized children, female infanticide, fatal neglect of female children, physical destruction of homes, and abduction of children for adoption abroad. As discussed above, the law itself is fairly innocuous in its language. Its enforcement, however, has created unimaginable heartbreak and financial ruin for those who have failed to comply.

Fanatical, callous, brutal officials have committed grave atrocities against women and families who have violated the one-child policy. Forced abortions - some of them committed in the third trimester and even in the ninth month of pregnancy-have not been uncommon. ${ }^{166} \mathrm{In}$

166. Li, supra note 126, at 105. See also U.S. Dep’t of State, Bureau of Democracy, H.R. and Lab., 2015 Country Reports on Human Rights Practices: China (2015), https://www.state.gov/j/drl/rls/hrrpt/2015/ [https://perma.cc/F2FN-KEHV], at 54:

Intense pressure to meet birth-limitation targets set by government regulations resulted in instances of local family-planning officials using physical coercion to meet government goals. Such practices included the mandatory use of birth control and the forced abortion 
scathing testimony to the House Subcommittee on International Operations and Human Rights in 1998, a former local administrator of China's population control program described the consequences for noncompliance: "Should a woman be found pregnant without a certificate, an abortion is performed immediately, regardless of how many months pregnant she is." 167 The administrator related in graphic detail the fate of a woman in her ninth month of pregnancy who had become pregnant without government approval:

Once I found a woman who was nine months pregnant, but did not have a birth-allowed certificate. According to the policy, she was forced to undergo an induced abortion. In the operating room, I saw the child's lips were moving and how its arms and legs were also moving. The doctor injected poison into its skull and the child died and it was thrown into the trash can. ${ }^{168}$

The former population control policy administrator also told of bulldozed homes, detention of pregnant women, detention of family members of people who violated the policy, forced and coerced sterilization, and heavy fines. ${ }^{169}$

In addition to the agonizing treatment of fully viable unborn children and their parents, children born in contravention of the policy also suffer gross human rights violations. In China, children born to parents lacking official permission to have them are known as heihaizi, which translates as "black children." ${ }^{170}$ These children are typically not eligible for the hukou, a document described as "a birth certificate, social security card, work permit, and internal passport all rolled up into one.” ${ }^{171}$ Life without a hukou generally means lack of access to school and medical care as a child, and, as an adult, the inability to work, open

of unauthorized pregnancies. In the case of families that already had two children, one

parent was often required to undergo sterilization.

167. Statement of Gao Xiao Duan, supra note 139, at 17.

168. Id. at 22. See also id. at 17 (recounting the story of a woman who became pregnant without seeking government approval, went into hiding, was found during her ninth month of pregnancy, and underwent a forced abortion).

169. Id. at $17-22$.

170. Steven W. Mosher, China's "Black Children" Will Come out of the Shadows, POPULATION RESEARCH INST. (2015), https://www.pop.org/chinas-black-children-will-come-out-ofthe-shadows/ [https://perma.cc/9XLE-RNDJ].

171. Id. 
a bank account, or even marry. ${ }^{172}$ An article by the Population Resource Institute describes the bleak existence of China's "illegal" children:

The tens of millions of undocumented Chinese children and young people are not merely marginalized, they are completely outside the bounds of Chinese society. And as non-persons, they have endured tremendous suffering. Unlike illegal immigrants in the U.S., who are generally treated with some compassion, the 'black children' have no rights at all. Anyone and everyone can mistreat them, and they are totally without recourse. If mugged, raped, or beaten, they would not think of going to the police, who would probably just brutalize them even more. ${ }^{173}$

Baby girls have also been the victims of human rights violations due to the one-child policy. Female infanticide, abandonment, and fatal neglect of girl babies rose in China after significant decline once the one-child policy was imposed. ${ }^{174}$ Exact numbers are impossible to come by, among other reasons because many families have concealed the birth of their daughters. ${ }^{175}$ Many girls, however, were abandoned in orphanages that committed shocking neglect and abuse, ${ }^{176}$ murdered or fatally neglected by their parents, or given lower priority for medical care than their brothers. ${ }^{177}$

As a direct result of China's often brutal enforcement of its family planning policies and the concomitant disposal of female fetuses and children, China now faces a dual demographic crisis. China currently has a birth rate of only 1.6 children per woman, ${ }^{178}$ far below the replacement rate of 2.1. ${ }^{179}$ With an aging population and too few young people to

172. Katie Hunt \& Serena Dong, China Says it Will Give Rights to Undocumented Children, CNN (Dec. 11, 2015), http://www.cnn.com/2015/12/11/asia/china-unregistered-citizensrights/index.html [https://perma.cc/YWX2-J7C4].

173. Mosher, supra note 170

174. Sten Johansson \& Ola Nygren, The Missing Girls of China: A New Demographic Account, 17 Population \& DeVelopment Rev. 40-41 (1991).

175. Case Study: Female Infanticide, GENDERCIDE WATCH, http://www.gendercide.org/case_infanticide.html [https://perma.cc/9283-XYPS].

176. Death by Default: A Policy of Fatal Neglect in China's State Orphanages, Human Rights Watch (2006).

177. Justin Parkinson, Five Numbers That Sum Up China's One-Child Policy, BBC News MAG. (Oct. 29, 2015), http://www.bbc.com/news/magazine-34666440 [https://perma.cc/4HZL5XZA].

178. Fertility rate, total (births per woman), THE WORLD BANK, http://data.worldbank.org/indicator/SP.DYN.TFRT.IN [https://perma.cc/X4RP-QVTD].

${ }^{179}$ See Tim Searchinger et al., Achieving Replacement Level Fertility, WORLD RESOURCES INST. (Aug. 2013), at 1, http://www.wri.org/publication/achieving-replacement-level-fertility [https://perma.cc/W2TJ-99MK] (“'Replacement level fertility' is the total fertility rate- the average 
support its elders, China faces a severe shortage of workers. ${ }^{180}$ Additionally, a cultural preference for sons, combined with refined ultrasound technology and wide availability of elective abortion, has created a significant gender imbalance. ${ }^{181}$

\section{Demographic Crises: A Shortage of Young People and a Shortage of Females}

China's one-child policy has been called "one of the most glaring policy mistakes that China has made in its modern history," ${ }^{182}$ not so much because of the human rights violations China inflicted on its people in enforcing the policy, but because of the potentially catastrophic effect it has had on China's ability to sustain growth and support an increasingly elderly population. ${ }^{183}$ China, a country that had six young people for every one elderly person as recently as 1976, is now projected to have two elderly people for every one young person by 2035. ${ }^{184}$ While many developed countries have aging populations as a result of lower fertility rates and longer life expectancies, China's rapidly shifting demographics are cause for heightened concern. As the authors of a comprehensive report on China's aging population point out, “[w]hile today's developed countries were all affluent societies with mature welfare states by the time they became aging societies, China is aging at a much earlier stage of economic and social development." ${ }^{185}$ It

number of children born per woman —at which a population replaces itself from one generation to the next, without migration.").

180. Howard W. French, China's Twilight Years, THE ATlantiC (June 2016), https://www.theatlantic.com/magazine/archive/2016/06/chinas-twilight-years/480768/ [https://perma.cc/86GL-9K72].

181. The Most Surprising Demographic Crisis, The Economist (May 5, 2011), http://www.economist.com/node/18651512 [http://perma.cc/5KWU-AC6M].

182. David McKenzie, For China, Three Decades of One-Child Policy Proves Hard to Undo, CNN (Mar. 30, 2015), http://www.cnn.com/2015/03/30/asia/china-one-child-policyundo/index.html [https://perma.cc/635H-7W43] (quoting Professor Wang Feng, a leading demographic expert on China). See also French, supra note 180 (referring to the one-child policy as "one of history's great blunders").

183. See Kristof, supra note 158 (paraphrasing leading Chinese demographer Wang Feng, who opines that the policy is "worse even than the Cultural Revolution or the Great Leap Forward (which led to the worst famine in world history)").

184. Richard Jackson, Keisuke Nakashima, \& Neil Howe, China's Long March to Retirement Reform: The Graying of the Middle Kingdom Revisited, Ctr. for Strategic \& Int'l Studies, PRUDENTIAL FOUNDATION (2008), at 2, http://news.prudential.com/images/20026/ US\%20GOTMK\%20English\%20Bro\%2009\%204_3.pdf [https://perma.cc/JJ46-T34X].

185. Id. 
is therefore not as prepared to care for its aging citizens, ${ }^{186}$ many of whom are poor rural workers who do not have savings and have not paid into a national social security plan. ${ }^{187}$

In addition to not having savings, many of the Chinese elderly lack caregivers, a role traditionally filled by the wife of the eldest son. ${ }^{188}$ The one-child policy has led to a gender imbalance fueled by a strong cultural and religious preference for male children. Analysis of data from a 2005 population survey shows an alarming ratio of 120 men to 100 women, ${ }^{189}$ which by 2020 will result in more than 30 million excess single men. ${ }^{190}$ The preference for male children derives from the Confucian tradition that male children are responsible for maintaining and caring for their elderly parents. ${ }^{191}$ Culturally, the actual responsibility for caring for elderly parents falls to daughters-in-law. ${ }^{192}$ But the infanticide, fatal neglect, and-more commonly-sex-selective abortions that have accompanied the one-child policy have led to a severe shortage in potential brides, a significant social concern. ${ }^{193}$

China has recognized the demographic consequences of its onechild policy and has attempted to rectify it by changing it to a two-child policy as of January 2016. China has not, however, acknowledged the tremendous emotional cost of the policy, from parents who desired more children but did not have them because of the law, to parents who suffered the horror of forced abortions. China's response to criticism of its policy is that it is necessary for the common good. ${ }^{194}$ The following

186. Feng Wang, China's Population Destiny: The Looming Crisis, BROOKINGS INST. (Sept. 30, 2010), https://www.brookings.edu/articles/chinas-population-destiny-the-looming-crisis/ [https://perma.cc/FX3E-SJZR].

187. See generally, Jackson et al., supra note 184 (detailing the weaknesses of China's retirement system).

188. Id. at 14

189. Wei Xing Zhu, Li Lu, \& Therese Hesketh, China’s Excess Males, Sex Selective Abortion, and One Child Policy: Analysis of Data From 2005 National Intercensus Survey, BRIT. MEDICAL J. (2009), at 2, http://www.bmj.com/content/bmj/338/bmj.b1211.full.pdf [http://perma.cc/6QR6$64 \mathrm{EJ}]$.

190. French, supra note 180.

191. Jackson, supra note 184, at 16.

192. Id. at 14 .

193. Wang, supra note 186.

194. See Carter J. Dillard, Rethinking the Procreative Right, 10 Yale Hum. RTS. \& DEV. L.J. 1, 36 (2007):

China has never recognized a conflict between its family-planning policy and the broad procreative right, and, in fact, it has argued that its policy is perfectly consistent with international law. It has done so not based simply on notions of state sovereignty, but upon notions of competing rights, and its obligations to protect children and society as a whole from unjustified and destructive behavior. 
section deals with the question of which good is greater: an individual's right to reproductive freedom, or the state's interest in providing for the moral or economic health of its people.

\section{WHETHER STATE INTERESTS SHOULD EVER SUPERSEDE AN INDIVIDUAL’S RIGHT TO REPRODUCTIVE FREEDOM}

The preceding analyses of Chinese and U.S. laws restricting reproductive freedom provide the background for the ultimate question this Article seeks to address through the framework of human rights law: can compelling state interests ever supersede an individual's right to reproductive freedom? The scholarship on this question is extensive, but the answer remains elusive. Without trying to answer the larger esoteric question of which is the greater good-reproductive freedom or the laudable state goals of protecting prenatal life and promoting sustainability - this Article analyzes discrete means of achieving state goals and evaluates whether they are legitimate according to international human rights concepts.

\section{A. Compulsory Sex Education Achieves the Goals of Abortion Prevention and Population Control in the Least Coercive Manner and Within the Bounds of Human Rights Norms.}

Compulsory sex education serves the goal of preventing unwanted pregnancies that might result in elective or forced abortion. In order to be effective, the information must be medically accurate and include information on contraception. While many religious and moral conservatives in both the United States and China object to sex education unless it is limited to abstinence education, ${ }^{195}$ such objections are inconsistent with the overall goals of protecting prenatal life and preventing unwanted pregnancy. ${ }^{196}$

195. Jemimah Steinfeld, Do Chinese Classrooms Need to Talk About Sex?, CNN (June 19, 2014), http://www.cnn.com/2014/06/19/world/asia/china-sex-education/index.html [http://perma.cc/ 6U6C-C3XB] (quoting Tao Lin, president of the World Association of Chinese Sexologists: "Contradictions arise between radical and conservative, right and wrong. The radical may explain the use of condoms in middle school while the conservative still insist[s] on abstinence in college").

196. See Laurie Burkitt \& Yang Jie, China Performs 13 Million Abortions per Year, State Media Says, WALL ST. J. (Jan. 28, 2015), https://blogs.wsj.com/chinarealtime/2015/01/28/chinaperforms-13-million-abortions-per-year-state-media-says/_ [http://perma.cc/6D4M-MU7N] (referencing a report by China's National Health and Family Planning Commission stating that 13 million abortions take place in China every year as a result in large part of inadequate sex education). 
Compulsory sex education could be challenged as an infringement of the right to religious freedom, a right guaranteed by the U.S. Constitution, ${ }^{197}$ as well as international law. ${ }^{198}$ In the United States, the courts have long recognized the right of parents to educate their children as they see fit. ${ }^{199}$ Moreover, as advocates of compulsory sex education acknowledge, mandatory comprehensive sex education "would expose the children to ideas that the parents find offensive, and it would make more difficult parental efforts to pass along to their children religious precepts that they hold dear." ${ }^{200}$ However, "requiring children to receive comprehensive sex education ... is not compelling [parents] or their children to engage in conduct prohibited by their religion or to refrain from conduct mandated by their religion," ${ }^{201}$ nor is it an unreasonable or unacceptable form of coercion in light of the important interest, one shared by the state and parents, of protecting prenatal life by preventing unwanted pregnancies that could lead to abortion. ${ }^{202}$ It is also arguably the least coercive method of achieving the often interrelated goals of preventing unwanted pregnancy and preventing recourse to abortion.

\section{B. Financial Incentives and Penalties Prevent Excessive Population Growth Without the Use of Physical Force but may Nevertheless Violate Human Rights Norms.}

Financial incentives and penalties are another means of achieving the state goal of population control. These include withdrawal of

\footnotetext{
197. U.S. CONST. amend. I.

198. See International Covenant on Civil and Political Rights, supra note 11 ("Everyone shall have the right... to have or to adopt a religion or belief of his choice, and freedom, either individually or in community with others and in public or private, to manifest his religion or belief in worship, observance, practice and teaching.").

199. See, e.g., Pierce v. Soc'y of the Sisters of the Holy Names of Jesus \& Mary, 268 U.S. 510, 534 (1925) (striking down a state statute prohibiting private school education because it "unreasonably interferes with the liberty of parents and guardians to direct the upbringing and education of children”); Wisconsin v. Yoder, 406 U.S. 205 (1972) (allowing an exemption from compulsory high school education for Amish children whose parents wished for them to exit the public school system after eighth grade).

200. Gary J. Simson \& Erika A. Sussman, Keeping the Sex in Sex Education: The First Amendment's Religion Clauses and the Sex Education Debate, 9 S. CAL. ReV. L. \& Women's STUD. 265, 273 (2000).

201. Id. at 274.

202. See Lee, supra note 1, at 336 (identifying "torture; other cruel, inhuman, or degrading treatment or compulsory sterilization or abortion” as unreasonable and unacceptable coercion, and emphasizing the importance of "education, information and shame, as well as other incentives and disincentives that are consonant with human rights"). See also id. at 338 ("Inherent in responsible parenthood is the need to balance the individual with the collective right-the rights of children and those of the society as a whole.”).
} 
maternal benefits after a certain number of children, the withholding of a tax deduction after a certain number of children, cash payments for undergoing a sterilization procedure, cash payments for limiting family size, ${ }^{203}$ and caps on public benefits for poor families. ${ }^{204}$ While financial incentives and penalties are far less coercive than the actual forced termination of a pregnancy, a clear violation of international law, such methods are inherently coercive and therefore suspect.

As a matter of international law, incentive and disincentive programs are acceptable so long as they do not violate human rights. ${ }^{205}$ Such plans, however, are not favored. Instead, "[g]overnments are encouraged to focus most of their efforts towards meeting their population and development objectives through education and voluntary measures rather than schemes involving incentives and disincentives." 206

The reason for the reluctant acceptance of incentive and disincentive programs is the disproportionate effect that such programs may have on the poor. ${ }^{207}$ The poor may be pressured by economic necessity to consent to sterilization or other measures in exchange for money. ${ }^{208}$ The poor are also more impacted by fines or taxes designed to

203. Edmund H. Kellogg, Reform of Law Affecting Population Growth: Recent Developments, 10 J. INT'L L. AND ECON. 1, 29-31 (1974).

204. See Dandridge v. Williams, 397 U.S. 471 (1970) (upholding a Maryland regulation limiting Aid for Dependent Children (AFDC) allocations to no more than \$240 or \$250 per family regardless of family size). See also State v. Kline, 155 Ore. App. 96 (1998) (holding that prohibiting an abusive father from procreation until completion of counseling was not unconstitutional); State v. Oakley, 245 Wis. 2d 447 (2001) (holding that a probation condition that infringed on the right to procreate was valid in a prosecution for refusing to pay child support).

205. See Rep. of the U.N. World Population Conference, at I 34, U.N. Doc. E/Conf. 60/19, U.N. Sales No. E.75.XIII.3 (1974) (concluding that incentive and disincentive schemes are permissible but cautioning that "they should not violate human rights").

206. Rep. of the Int'l Conference on Population and Dev., at 9 7.22, U.N. Doc. A/CONF.171/13 (1994) http://www.un.org/popin/icpd/conference/offeng/poa.html [http://perma.cc/2V4Y-BAR3].

207. See, e.g., Note, Legal Analysis and Population Control: The Problem of Coercion, 84 HARV. L. REV. 1856, 1858 (1971) (noting that the decision in Dandridge v. Williams, supra note 204, in which the Court upheld a Maryland regulation limiting AFDC allocations to no more than $\$ 240$ or $\$ 250$ per family regardless of family size, "appears to sanction state imposition of financial disincentives against having more children and to dismiss the parents' claim that reproductive autonomy with respect to state benefit programs is a constitutionally protected freedom"). But see Mona Ma, A Tale of Two Policies: A Defense of China's Population Policy and an Examination of U.S. Asylum Policy, 59 Clev. ST. L. Rev. 237, 257 (2011) (supporting China's system of fines on the basis that " $[t] o$ avoid the negative social influence of flouting violations and to make sure the policy is enforced in an even-handed manner, the fines on the wealthy are set many times higher than for the average citizens").

208. Note, supra note 207, at 1860. 
punish or disincentivize procreation. ${ }^{209}$ Some scholars, however, find monetary incentives and disincentives to be acceptable, particularly as an alternative to other more coercive or intrusive means. ${ }^{210}$ Once we enter the realm of forced abortion and forced child-bearing, however, the gray area of what constitutes permissible coercion dissipates considerably.

\section{Forced Abortion, Forced Sterilization, and Forced Child-Bearing are Inconsistent with Human Rights Principles.}

Scholars and policymakers in the United States almost universally agree that forced abortion and forced sterilization clearly violate international human rights norms. ${ }^{211}$ The United States even took the extraordinary measure of amending its asylum law to facilitate the approval of asylum applications based on subjection to or resistance against forced abortion, involuntary sterilization, or other means of coercive population control. ${ }^{212}$ Especially in light of the many effective

209. Id. at 1891 ("Penalizing excessive childbearing by heavier taxation might make it difficult to maintain a family adequately or to hold it together.”).

210. See, e.g., Lee, supra note 1, at 338 ("Since incentives and disincentives partake of the nature of carrots and sticks, rewards and punishment - which contribute even to the attainment of excellence in 'education' itself - it is not clear what is to be gained by their removal from the population field.”).

211. See, e.g., Thomas A. Brown II, Forced Abortions and Involuntary Sterilization in China: Are the Victims of Coercive Population Control Measures Eligible for Asylum in the United States?, 32 SAN DIEGO L. REV. 745 (1995) (arguing that China's population control program is persecutory); Ying Chen, China's One-Child Policy and Its Violations of Women's and Children's Rights, 22 N.Y. INT'L L. REV. 1 (2009) (asserting that “[f]orced abortion and sterilization are inhumane and unacceptable in modern society"); Ellen Keng, Population Control Through the One-Child Policy in China; Its Effects on Women, 18 WOMEN's RTS. L. REP. 205 (1997) (discussing the emotional, physical, social and economic effects of China's coercive population control practices on Chinese women); Hearing Before the Subcomm. on Int'l Operations and Human Rights of the H. Comm. on Int'l Relations, supra note 139 (statement of Rep. Lantos, Member, House Subcomm. on International Operations and Human Rights) ("There are few crimes against human beings which are more horrendous, more despicable, more outrageous than the practice of forced abortion and forced sterilization. Such brutal violations of human rights must be condemned across the political spectrum . . . .). See also, supra Part II.A. (discussing the various international instruments that identify reproductive freedom and bodily integrity as fundamental human rights). But see Ma, supra note 207, at 259:

Although forced abortions should be utilized sparingly and should only be used as a last resort, they should not be abolished because they serve as a threat that deters people from violating the policy. Though extreme, the threat of forced abortions is a necessary safeguard to ensure the overall effectiveness of the policy. Of course, actual violations should be punished, or the threat of abortion will lose its deterring function.

212. Illegal Immigration Reform and Immigrant Responsibility Act of 1996, Pub. L. No. 104208, div. C, § 601(a)(1), 110 Stat. at 3009-689 (codified at 8 U.S.C. § 1101(a)(42)(B) (2000)). But see Lori K. Walls, The Persecutor Bar in U.S. Immigration Law: Toward a More Nuanced 
ways of preventing unwanted pregnancy through less coercive means, resorting to such brutality is unjustifiable.

Forced child-bearing is also a violation of human rights, as the following Canadian court stated regarding a woman denied the freedom to choose whether to terminate or continue with a pregnancy:

She is truly being treated as a means-a means to an end which she does not desire but over which she has no control. She is the passive recipient of a decision made by others as to whether her body is to be used to nurture a new life. Can there be anything that comports less with human dignity and self-respect? How can a woman in this position have any sense of security with respect to her person? ${ }^{213}$

Similarly, scholars who subscribe to the position that human rights law applies only to viable and born humans agree that "[a]bortion is ... indispensable to women's equality, dignity and rights as a human being." 214

Others, as discussed at length earlier, strongly believe that the induced termination of prenatal life is a clear violation of human rights. The lack of consensus on the morality of abortion indicates that the definition of "personhood" is intensely personal and often religious. ${ }^{215}$ Even some opponents of abortion believe that due to the "extreme lack

Understanding of Modern "Persecution" in the Case of Forced Abortion and Female Genital Cutting, 16 PAC. RIM L. \& POL'Y J. 227, 246 (2007) (stating that "the notion that forced abortion or sterilization is a transparent human rights violation, as obvious as the persecution of the Jews under Nazi Germany, is undermined by the fact that the U.S. government refused to grant asylum on this ground for decades, until 1996”).

213. Morgentaler, Smoling and Scott v. R. and the Attorney General of Canada, 44 D.L.R. 4th 385, 492 (Can. 1988).

214. Rhonda Copelon, Christina Zampas, Elizabeth Brusie, Jacqueline deVore, Human Rights Begin at Birth: International Law and the Claim of Fetal Rights, 13 ReproduCtive HeALtH MATTERs 120, 126 (2005). See also Hernandez, supra note 37, at 324-25:

States' regulation of reproductive freedom to achieve population goals ... or to placate influential religious institutions impermissibly erodes the integrity of an individual and precludes such individual's exercise of his or her rights of privacy, health, equality, or religion. Consequently, a state cannot regulate reproductive freedom without violating such individual's human rights as those rights have evolved since the Nuremburg Trials.

215. See, e.g., Peter S. Wenz, Abortion Rights As Religious Freedom 188-89 (1992) (arguing that "religion may legitimately matter where the death penalty, the environment, and animals are concerned” because these involve 'secular values,' but that many anti-abortion laws are invalid because "the personhood and right to life of young fetuses is a religious matter"). See generally, RONALD DWORKIN, LIFE’s DOMINION, 160-68, (Alfred A. Knopf ed.,1993) (arguing that disputes over the morality of abortion are fundamentally religious and thus the right to abortion is protected by the First Amendment). 
of consensus" 216 on whether first trimester abortions should be legal, laws that criminalize them "are likely to be unstable." ${ }^{217}$ When presented with a conflict between religious views, morals, or particular worldviews, internationally recognized principles of individual liberty ${ }^{218}$ should govern. ${ }^{219}$ This is especially true in light of the fact that attempts to govern morality by limiting access to contraception and comprehensive sex education directly impede the ostensibly higher goal of protecting prenatal life.

Any law that infringes on the right of an individual to determine whether and when to procreate to the extent that the individual is subjected to forced abortion, forced sterilization, or forced child-bearing far exceeds the "element of compulsion [that] underscores the effectiveness of all law" in order to "ensure social harmony." 220 Those who believe that the greater good lies in something other than individual freedom, be it protecting human life at all stages of development or providing for the collective good, have ample means at their disposal to "support[] and gradually extend[] a pro-life consensus"221 or to "influence and obtain compliance regarding reproductive behaviour."222 As prominent human rights scholars have argued:

[T] he idea that individuals in the present generation will not, left to their own free desires, make sound decisions, and therefore should be persuaded or forced to sacrifice for the good of future generations,

\footnotetext{
216. Michael J. Perry, Religion, Politics, and Abortion, 79 U. Det. Mercy L. ReV. 1, 30 (2001).

217. Id.

218. See supra Part II.A.

219. See Mark A. Graber, Constitutional Democracy, Human Dignity, and Entrenched Evil, 38 PEPP. L. REV. 889, 897 (2011):

Abortion in contemporary politics and slavery in the nineteenth century highlight how debate in democracies tends to be between factions with very different understandings of human dignity, not between the party of human dignity and the party of self-interest. When persons have sincere beliefs that the genders have different destinies, that different races cannot share the same political space, that the unborn have fewer rights than the born, or that a four-cell blob with human DNA has the same rights as a human adult, appeals to the constitutional commitment to human dignity or the constitutional ban on naked preferences are likely to do no political, intellectual, or academic work.

220. Babor, supra note 8, at 114-15.

221. Perry, supra note 216, at 30.

222. Babor, supra note 8, at 114-15. See also, Sen, supra note 38, at 1061:

Given the basic importance of reproductive freedom, its denial in favor of coercive restrictions can be justified - if at all - only by suitably strong positive consequences, involving for example well-being and economic security .... . Furthermore, it is not clear that coercion works faster than what can be achieved through voluntary social change and development.
} 
rests on several faulty assumptions... One is that the only way to lower population growth is through authoritarian enforcement of harsh measures. Another is that imposition of harsh measures will lead to slower population growth and improved socioeconomic development. Given that so little is known about the impact of present behavior on the future, neither notion justifies serious interference with human rights respecting reproductive choice. ${ }^{223}$

\section{CONCLUSION}

In 2016, China's one-child policy ended, as have the laws of several U.S. states seeking to impose unconstitutional restrictions on access to abortion. In China, families who wish to have two children may now do so without fear of fines, forced or coerced sterilization, or forced or coerced abortion. In the United States, thousands of women at risk of an unwanted pregnancy retained their constitutionally protected right to decide for themselves whether to continue with or abort an unwanted pregnancy. And yet, the debate over how far the state may go to achieve goals inconsistent with reproductive freedom rages on.

This Article has argued that sustainability and the protection of prenatal life are valid, compelling goals. China's and the United States' pursuit of their goals, however, has been and continues to be seriously flawed. In China, the vast bureaucracy charged with implementing its coercive population control policy has resorted to horrific means when research shows that less coercive means would not only have been effective, but may have lessened the demographic problems China now faces. In the United States, an obsession with imposing particular perspectives on sex-related morals has diminished the message aimed at protecting fetal life and has also increased the risk for unwanted pregnancies.

In light of these serious flaws, neither China's proponents of coercive population control nor the United States' opponents of abortion can successfully argue that their interests supersede an individual's right to reproductive freedom, or that the means by which they pursue their interests comport with human rights norms. China engaged in gross human rights violations, including induced labor of viable nine-monthold fetuses and subsequent murder of the newborn infants, in order to prevent overpopulation. China did so despite evidence that less coercive methods were effective and despite warnings from demographers that the obsession with achieving population control would lead to a

223. See also Boland et al., supra note 9 , at 97. 
precipitous and potentially catastrophic decline in women and young people. United States opponents of abortion would force women to bear children and deal with the severe emotional, physical, social, and financial consequences, while doing little or nothing to prevent unwanted pregnancy via contraception and sex education. Neither China's population control juggernaut nor the United States' antiabortion movement's attempt to govern sexuality, by emphasizing its role as the protector of prenatal life, respect a fundamental life decision: whether and when to have children and how many to have. When less restrictive methods for achieving state goals exist-methods short of forced abortion and forced sterilization in China, and access to contraception and sex education in the United States-there is no valid justification for forced child-bearing or forced abortion. 